\title{
Strategies to Increase the Value of Pomaces with Fermentation
}

\author{
Paulo E. S. Munekata ${ }^{1}$, Rubén Domínguez ${ }^{1}$ (D), Mirian Pateiro ${ }^{1}$ (D) Asad Nawaz ${ }^{2,3}$, Christophe Hano ${ }^{4}$, \\ Noman Walayat ${ }^{5}$ and José M. Lorenzo $1,6, *$ (D)
}

1 Centro Tecnológico de la Carne de Galicia, Rúa Galicia No. 4, Parque Tecnológico de Galicia, San Cibrao das Viñas, 32900 Ourense, Spain; paulosichetti@ceteca.net (P.E.S.M.); rubendominguez@ceteca.net (R.D.); mirianpateiro@ceteca.net (M.P.)

2 Jiangsu Key Laboratory of Crop Genetics and Physiology, College of Agriculture, Yangzhou University, Yangzhou 225009, China; 007298@yzu.edu.cn

3 Co-Innovation Center for Modern Production Technology of Grain Crops, Yangzhou University, Yangzhou 225009, China

4 Laboratoire de Biologie des Ligneux et des Grandes Cultures, INRA USC1328, Orleans University, CEDEX 2 , 45067 Orleans, France; hano@univ-orleans.fr

5 College of Food Science and Technology, Zhejiang University of Technology, Hangzhou 310014, China; Noman.rai66@gmail.com

6 Área de Tecnología de los Alimentos, Facultad de Ciencias de Ourense, Universidad de Vigo, 32004 Ourense, Spain

* Correspondence: jmlorenzo@ceteca.net

Citation: Munekata, P.E.S.; Domínguez, R.; Pateiro, M.; Nawaz, A.; Hano, C.; Walayat, N.; Lorenzo, J.M. Strategies to Increase the Value of Pomaces with Fermentation. Fermentation 2021, 7, 299. https:// doi.org/10.3390/fermentation7040299

Academic Editors: Giuseppa Di Bella and Alessia Tropea

Received: 28 October 2021

Accepted: 6 December 2021

Published: 8 December 2021

Publisher's Note: MDPI stays neutral with regard to jurisdictional claims in published maps and institutional affiliations.

Copyright: (c) 2021 by the authors. Licensee MDPI, Basel, Switzerland. This article is an open access article distributed under the terms and conditions of the Creative Commons Attribution (CC BY) license (https:/ / creativecommons.org/licenses/by/ $4.0 /)$.

\begin{abstract}
The generation of pomaces from juice and olive oil industries is a major environmental issue. This review aims to provide an overview of the strategies to increase the value of pomaces by fermentation/biotransformation and explore the different aspects reported in scientific studies. Fermentation is an interesting solution to improve the value of pomaces (especially from grape, apple, and olive) and produce high-added value compounds. In terms of animal production, a shift in the fermentation process during silage production seems to happen (favoring ethanol production rather than lactic acid), but it can be controlled with starter cultures. The subsequent use of silage with pomace in animal production slightly reduces growth performance but improves animal health status. One of the potential applications in the industrial context is the production of enzymes (current challenges involve purification and scaling up the process) and organic acids. Other emerging applications are the production of odor-active compounds to improve the aroma of foods as well as the release of bound polyphenols and the synthesis of bioactive compounds for functional food production.
\end{abstract}

Keywords: pressing residue; grape; apple; silage; animal production; enzyme production; polyphenols

\section{Introduction}

Pomace is the main residue (a humid, solid material) generated from the pressing of fruits and olives to obtain juices and olive oil, respectively. This residue is heterogeneous and may contain seeds, pulp, stems, and peels, depending on the source [1,2]. In terms of the global production of juices and olive oil, the amount of pomace produced every year achieves several millions of tons [3,4]. Its high organic matter, nutrients, and moisture content favor the growth of microorganisms to decompose this residue (the generation of greenhouse gases, unpleasant odors, and contamination of groundwater) and can attract pests, which ultimately leads to an important environmental impact [5]. Additionally, the consumption of juices [6,7] and olive oil [8-10] is expected to increase in the upcoming years. In this sense, the residues from these two sectors of the food industry are expected to increase.

Another important aspect related to pomaces is the presence of bioactive compounds that are lost when these residues are discarded. One of the most studied classes of phytochemicals are polyphenols. This class of compounds is characterized by the antioxi- 
dant [11-13], antimicrobial [3,12], anti-inflammatory [13], and anti-diabetic [14] activities tested in vitro and in vivo. This scenario can be seen as a relevant opportunity to explore strategies to improve the management of pomace and reduce its environmental impact.

In this sense, the concept of a circular economy is favored to improve the sustainability in this sector of the food industry, i.e., transforming residues into raw materials with highadded value and connecting them with other chains of food processing [15]. Moreover, a circular economy is one of the principles of the European Green Deal that aims to improve the efficiency of resource use and to cut pollution, for instance [16,17]. Recent publications support the potential utilization of this strategy [18-24]. It is also important to mention that the reutilization of residues of the food industry and the consequent development of food products are concepts supported and well-accepted by consumers [25,26].

Among the possible solutions to manage pomaces, fermentation has been suggested to obtain high-added value products and compounds. Moreover, fermentation can be seen as an important and more sustainable strategy to treat food industry residues $[2,27,28]$. Thus, this review aims to provide an overview of the utilization of fermentation (mainly involving lactic acid bacteria and yeasts) and biotransformation (biotransformation) of pomace in the production of silage and supplement feed for animal, enzymes, polyphenols, bioactive compounds (release of bound polyphenols and the synthesis of fatty acids and carotenoids), odor-active volatile compounds, and organic acid production.

\section{Utilization in Silage or as a Feed Supplement for Animal Production}

The feeding of animals reared for food production is one of the possible applications of fermented pomaces (Figure 1), for which there are two main strategies: adding the pomace in silage production or fermenting/biotransforming the pomace and using it as feed supplement (Table 1). Regarding the first strategy, the production of silage consists of preserving pasture grass for further use (especially during dry periods). The process occurs mainly by fermenting pasture with bacteria that are naturally or strategically added to acidify the material and delay microbial and biochemical spoilage [29]. Considering the importance of silage and the fermentation process, many studies have explored the effect of pomace in the characteristics of silage and its effect in animal health and performance.

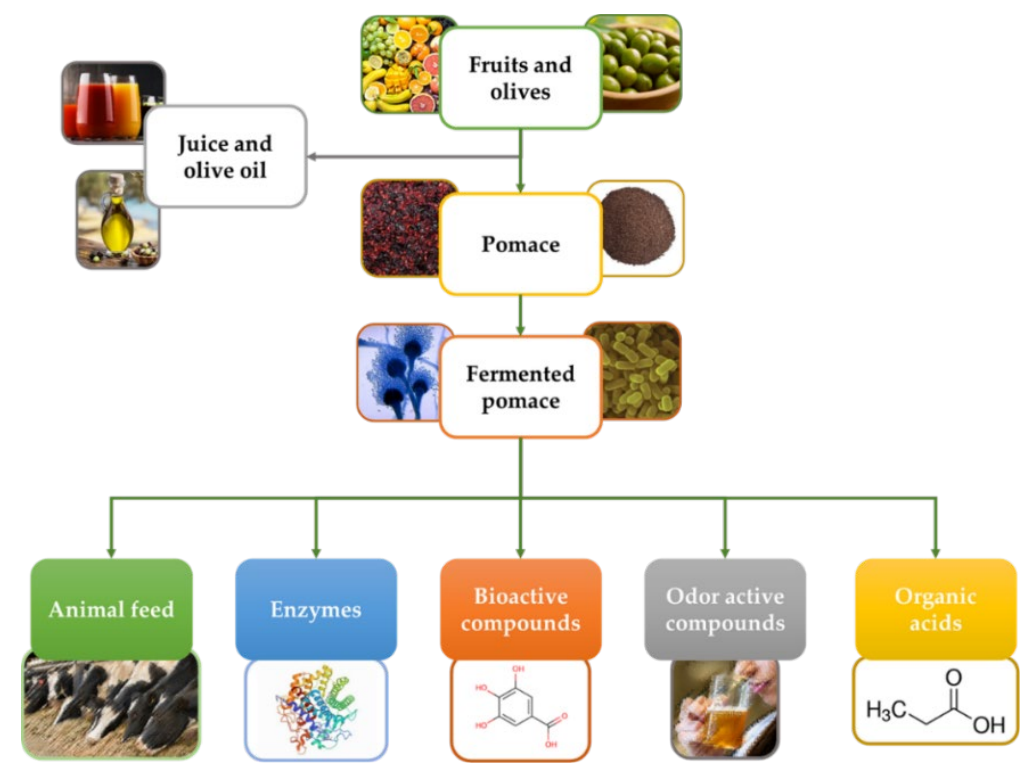

Figure 1. Schematic representation of strategies to valorize pomaces with fermentation. 
Table 1. Effect of fermentation in the characteristics of silage produced from apple, white mulberry, and grape pomace.

\begin{tabular}{|c|c|c|c|}
\hline Source & Experimental Conditions & Effect in Silage Characteristics & Ref. \\
\hline Apple pomace & $\begin{array}{l}\text { Alfalfa hay, timothy hay, soybean meal, and } \\
\text { vitamin and mineral supplement, pomace }(0 \text {, } \\
5,10 \text {, and } 20 \%), 3.4-22.4^{\circ} \mathrm{C} \text {, and } 60 \text { days }\end{array}$ & $\begin{array}{l}\text { Increased } \mathrm{pH} \text {, ethanol, acetic acid, and } \\
\text { ammonia nitrogen levels; reduced lactic } \\
\text { acid content }\end{array}$ & [30] \\
\hline Apple pomace & $\begin{array}{l}\text { Maize, wheat bran, soybean meal, timothy } \\
\text { hay, alfalfa hay and vitamin-mineral } \\
\text { supplement, pomace ( } 20 \% \text { in silage), } \\
4.4-25.8^{\circ} \mathrm{C} \text {, and } 60 \text { days }\end{array}$ & $\begin{array}{l}\text { Increased } \mathrm{pH} \text { and ethanol content; reduced } \\
\text { lactic and acetic acid, and ammonia } \\
\text { nitrogen contents }\end{array}$ & [31] \\
\hline Grape pomace & $\begin{array}{l}\text { Calotropis procera, pomace }(0,10,20,40 \% \text { in } \\
\text { silage), and } 90 \text { days }\end{array}$ & $\begin{array}{l}\text { Increased ethanol, acetic, propionic and } \\
\text { butyric acid contents, effluent loss and gas } \\
\text { loss; reduced soluble carbohydrate and } \\
\text { lactic acid content and digestibility; no } \\
\text { effect in pH }\end{array}$ & [32] \\
\hline Grape pomace & $\begin{array}{l}\text { Sweet sorghum silage, pomace }(0,5,10 \text {, } \\
\text { and } 15 \% \text { in silage), and } 90 \text { days }\end{array}$ & $\begin{array}{l}\text { Increased acetic acid (only } 10 \% \text { ) and total } \\
\text { polyphenol content; reduced water-soluble } \\
\text { carbohydrates, lactic acid (only } 15 \% \\
\text { treatment), and butyric acid contents; no } \\
\text { effect in dry matter and protein neutral and } \\
\text { detergent fiber contents, } \mathrm{pH} \text {, and ammonia } \\
\text { nitrogen level }\end{array}$ & [33] \\
\hline White mulberry pomace & $\begin{array}{l}\text { Meadow grass, pomace }(0,25,50,75, \\
\text { and } 100 \% \text { in silage), and } 60 \text { days }\end{array}$ & $\begin{array}{l}\text { Increased gas production, organic matter } \\
\text { digestibility, and metabolizable energy }\end{array}$ & [34] \\
\hline
\end{tabular}

Using pomace as a raw material for silage production may shift the characteristics of silage and change its content and composition of organic acids, digestible matter, and $\mathrm{pH}$. These results were reported in studies with apple pomace that also indicated a reduction in the production of lactic acid [30,31]. Along with the increase in ethanol content in silage, the $\mathrm{pH}$ was increased, and the accumulation of lactic acid was reduced in relation to silage without pomace. However, these studies also indicated an unclear effect in the accumulation of ammonia nitrogen.

In the case of grape pomace, the depletion in lactic acid content and the increase in the production of other organic acids, polyphenol content, effluent and gas loss were also reported in two recent studies [32,33]. Both studies did not indicate significant differences in the $\mathrm{pH}$ of silage. It is relevant to mention that the study carried out by Li et al. [33] also evaluated the combination of grape pomace with the starter culture composed of Lactobacillus plantarum and Lactobacillus buchneri. These microorganisms led to a better control of fermentation and quality of silage by favoring the accumulation of lactic and acetic acid, water soluble carbohydrates, and crude protein. Moreover, ammonia nitrogen levels were reduced and no effect in the neutral detergent fiber content and the $\mathrm{pH}$ of silage were reported. A related experiment evaluated the production of silage with white mulberry pomace with meadow grass [34]. In this case, significant effects in organic matter digestibility and metabolizable energy, as well as in gas production, were reported.

Since silage is an important component for animal production in periods and regions of reduced feed availability, some studies reported the effect of silage with pomace and fermented pomace in animal nutrition, health and the composition and characteristics of foods obtained from animals in these experimental diets (Table 2). For instance, recent experiments reported the effect of silage added with apple pomace in the diet of Suffolk wethers $[30,31]$. In both cases, significant reductions in digestibility and nitrogen retention, in relation to the control diet, were reported. No effect in feed intake between control and experimental diets were indicated in these studies. 
Table 2. Effect of fermented apple, grape, pomegranate, olive, and tomato pomaces in animal production and foods obtained from animals fed with these fermented pomaces.

\begin{tabular}{|c|c|c|c|c|}
\hline Source & Experimental Conditions & Animals and Study Characteristics & Effect in Animal Production and Related Food & Ref. \\
\hline Apple pomace & $\begin{array}{l}\text { Silage: alfalfa hay, timothy hay, soybean meal, and } \\
\text { vitamin and mineral supplement, pomace }(0,5,10 \text {, } \\
\text { and } 20 \%), 3.4-22.4^{\circ} \mathrm{C} \text {, and } 60 \text { days }\end{array}$ & $\begin{array}{l}\text { Suffolk wethers ( } 4 \text { animals), initial weight } \\
50.3 \mathrm{~kg} \text {, and } 21 \text { days of experiment }\end{array}$ & $\begin{array}{l}\text { Reduced digestibility, gross energy, and nitrogen } \\
\text { retention; no effect in feed intake and fiber content }\end{array}$ & [30] \\
\hline Apple pomace & $\begin{array}{l}\text { Silage: control feed, pomace }(14.8 \% \text { in } \\
\text { silage), } 9.7-20.1^{\circ} \mathrm{C} \text {, and } 21 \text { days }\end{array}$ & $\begin{array}{l}\text { Male Yorkshire } \times \text { Duroc } \times \text { Landrace pigs } \\
(10 \text { animals }) \text {, initial weight } 70 \mathrm{~kg} \text {, } \\
\text { and } 53 \text { days of experiment }\end{array}$ & $\begin{array}{l}\text { Animals: increased feed efficiency; reduced average } \\
\text { daily feed intake; no effect in finished body weight, } \\
\text { average, daily gain, carcass weight, back fat thickness } \\
\text { or dressing ratio } \\
\text { Back fat: increased moisture, linoleic acid (C18:2n6), } \\
\text { linolenic acid (C18:3) and arachidic acid; reduced } \\
\text { water holding capacity, palmitic acid (C16:0), } \\
\text { palmitoleic acid (C16:1) and heptadecenoic } \\
\text { acid (C17:1) proportion }\end{array}$ & [35] \\
\hline Apple pomace & $\begin{array}{l}\text { Silage: minced sardine, pomace }(15 \%), \\
\text { Lactobacillus plantarum (starter culture), } 35^{\circ} \mathrm{C} \\
\text { for } 7 \text { days }\end{array}$ & $\begin{array}{l}\text { Juvenile European sea bass fish ( } 240 \text { animals), } \\
\text { initial weight } 15 \mathrm{~g} \text {, and } 9 \text { weeks of experiment }\end{array}$ & $\begin{array}{l}\text { Increased feed conversion ratio, relative average daily } \\
\text { feed intake, leukocyte count, and carcass composition } \\
\text { (moisture, lipid and ash contents); reduced final body } \\
\text { weight, weight gain, specific growth rate, protein } \\
\text { efficiency, apparent net protein utilization, and } \\
\text { microvilli density }\end{array}$ & [36] \\
\hline Grape pomace & $\begin{array}{l}\text { Silage: sorghum, pomace }(0,10,20 \text {, and } 30 \%) \text {, } \\
\text { and } 7 \text { months }\end{array}$ & $\begin{array}{l}\text { Male mixed breed lambs ( } 24 \text { animals), initial } \\
\text { weight } 21.5 \mathrm{~kg} \text {, and } 35 \text { days of experiment }\end{array}$ & $\begin{array}{l}\text { No effect in performance, carcass composition, } \\
\text { and meat quality }\end{array}$ & [37] \\
\hline Grape pomace & $\begin{array}{l}\text { Silage: corn, water, starter culture, and pomace } \\
\text { ( } 43.6 \mathrm{~g} / \mathrm{kg} \text { feed) }\end{array}$ & $\begin{array}{l}\text { Landrace } \times \text { Large White }- \text { Duroc }- \text { Pietrain } \\
\text { piglets }(24 \text { animals), } \\
\text { and } 15 \text { days of experiment }\end{array}$ & $\begin{array}{l}\text { Animals: increased antioxidant defense system } \\
\text { response, average daily gain, growth of facultative } \\
\text { probiotic bacteria, and LAB; reduced oxidative stress } \\
\text { and pathogen } \\
\text { Meat: increased omega- } 3 \text { fatty acids content; } \\
\text { reduced n- } 6 / n-3 \text { ratio }\end{array}$ & [38] \\
\hline Grape pomace & $\begin{array}{l}\text { SSF: } 1 \mathrm{~kg} \text { substrate, Aspergillus niger, } 30^{\circ} \mathrm{C} \text {, and } 7 \text { days; } \\
\text { pomace }(15 \mathrm{~g} / \mathrm{kg} \text { feed })\end{array}$ & $\begin{array}{l}\text { Male Ross } 308 \text { broiler chicks ( } 140 \text { animals), } \\
\text { and } 42 \text { days of experiment }\end{array}$ & $\begin{array}{l}\text { Animals: increased body weight and serum CAT level; } \\
\text { reduced Clostridium perfringens count in cecum; no } \\
\text { effect in feed intake, feed conversion ratio, serum GPx } \\
\text { and SOD, other microorganism in cecum, and } \\
\text { intestinal morphology } \\
\text { Liver: no effect in pH and color }\end{array}$ & [39] \\
\hline
\end{tabular}


Table 2. Cont.

\begin{tabular}{|c|c|c|c|c|}
\hline Source & Experimental Conditions & Animals and Study Characteristics & Effect in Animal Production and Related Food & Ref. \\
\hline Olive pomace & $\begin{array}{l}\text { SSF: Two-step fermentation: Bacillus subtilis var. natto } \\
\text { N21, } 37^{\circ} \mathrm{C}, 2 \text { days; Lactobacillus casei, } 25-35^{\circ} \mathrm{C} \text {, } \\
\text { and } 5 \text { days; pomace }(7.5,15 \text {, and } 30 \%)\end{array}$ & $\begin{array}{l}\text { Male Ross } 308 \text { broiler chicks ( } 1400 \text { animals), } \\
\text { initial weight } 44-47 \mathrm{~g}, \\
\text { and } 42 \text { days of experiment }\end{array}$ & $\begin{array}{l}\text { Animals: increased feed conversion ratio, antioxidant } \\
\text { status and defense system response; reduced body } \\
\text { weight gain, protein efficiency ratio, nutrient } \\
\text { digestibility, serum triglycerides and total cholesterol; } \\
\text { no effect in feed intake, serum LDL cholesterol, ALT } \\
\text { and AST } \\
\text { Breast meat: increased GPx and SOD; reduced fat and } \\
\text { cholesterol content, and lipid oxidation status; no } \\
\text { effect in moisture and protein }\end{array}$ & [40] \\
\hline Tomato pomace & $\begin{array}{l}\text { SSF: pomace ( } 10 \% \text { in silage), Lactobacillus plantarum } \\
\text { (starter culture), and } 30 \text { days }\end{array}$ & $\begin{array}{l}\text { Pregnant Holstein dairy cows ( } 50 \text { animals), } \\
\text { initial weight } 710-715 \mathrm{~kg} \text {, } \\
7 \text { days of experiment }\end{array}$ & $\begin{array}{l}\text { Animals: increased feed intake and digestibility, blood } \\
\text { cholesterol and HDL, IgA, IgG, IgM, and antioxidant } \\
\text { defense system response; no effect in feed intake, } \\
\text { digestibility, milk yield and composition } \\
\text { Milk: increased vitamin A, C, and E contents; no effect } \\
\text { milk yield and composition }\end{array}$ & [41] \\
\hline $\begin{array}{l}\text { Pomegranate } \\
\text { pomace }\end{array}$ & $\begin{array}{l}\text { SSF: } 100 \mathrm{~g} \text { substrate, Aspergillus niger, } 30^{\circ} \mathrm{C} \text {, } \\
\text { and } 7 \text { days; pomace ( } 5 \text { and } 10 \mathrm{~g} / \mathrm{kg} \text { feed) }\end{array}$ & $\begin{array}{l}\text { Male Ross } 308 \text { broiler chicks ( } 175 \text { animals), } \\
\text { initial weight } 39 \mathrm{~g} \text {, and } 42 \text { days of experiment }\end{array}$ & $\begin{array}{l}\text { Animals: increased crypt depth; reduced lipid } \\
\text { oxidation, Clostridium perfringens in cecum, and villus } \\
\text { height; no effect in body weight, feed intake and } \\
\text { conversion ratio, carcass characteristics, antioxidant } \\
\text { defense system response, and muscularis } \\
\text { mucosa thickness } \\
\text { Meat and liver: no effect in color and } \mathrm{pH}\end{array}$ & [42] \\
\hline
\end{tabular}

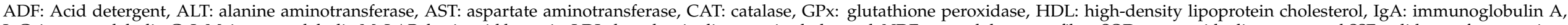

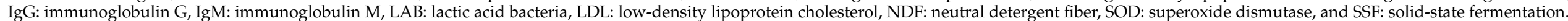


A related experiment with pigs fed with silage containing apple pomace indicated minimal or non-significant effects in the growth performance, except for a reduction in daily feed intake and an increase in feed efficiency in animals fed with apple pomace silage [35]. Additionally, this study also indicated a significant increase in the content of some individual polyunsaturated fatty acids in back fat, whereas the content of few saturated and monounsaturated fatty acids in back fat were reduced. This effect was attributed to the dietary fiber found in apple pomace that favored the growth of probiotic microorganisms in pig intestine and led to the potential changes in back fat fatty acid composition.

Another interesting strategy to use silage with apple pomace was reported for the production of fish. Davies et al. [36] studied the effect of a silage produced with apple pomace, minced sardine, and Lactobacillus plantarum as a starter culture in the production of juvenile European sea bass. In these animals, the silage with apple pomace improved the health status of fish, whereas growth performance indicators were reduced in relation to the control diet (without apple pomace).

The effect of feeding animals with silage containing grape pomace was also reported in recent studies but contrasting results have been reported. In the experiment carried out by Massaro Junior et al. [37], increasing levels of silage with grape pomace (up to 30\% in feed) did not cause significant changes in indicators of growth performance (initial and final body weight, average daily gain and feed conversion ratio), carcass characteristics (hot and cold carcass yield, for instance), and meat quality (such as $\mathrm{pH}$, shear force, lipid oxidation, and color) in lambs. Conversely, the use of silage produced with grape pomace in piglets induced the antioxidant defense system, reduced the indicators of oxidative stress, and the counts of pathogenic microorganisms (Campylobacter jejuni, for instance) in fecal samples [38]. Additionally, the meat produced from animals fed with the experimental diet had more omega- 3 fatty acids in comparison to the meat from animals fed with the control diet.

Fermentation in a solid state has also been explored to obtain potential feed additives for animal production. In the case of broiler chicks, the incorporation of fermented grape pomace in animal diets produced heavier animals with increased serum levels of catalase (a component of the antioxidant defense system) [39]. Additionally, no significant reductions in other components of the antioxidant defense system, intestinal morphology, and the $\mathrm{pH}$ or color of liver in the animals fed with silage containing grape pomace were reported in this study.

Olive pomace has been indicated as an interesting component to improve the diet of chicks [40]. Adding fermented olive pomace in animal feed enhanced the antioxidant status and the antioxidant defense system as well as reduced serum triglycerides and total cholesterol. Conversely, body weight gain was affected and no major effects in liver enzymes were indicated by the authors. The effects on animal health were also observed in meat in terms of reduced fat, cholesterol contents and lipid oxidation levels in breast meat. Another study indicated a favorable effect of solid-state fermented pomace in animal health [41]. In this case, the consumption of fermented tomato pomace improved health indicators (serum lipids and immune and antioxidant defense systems) in Holstein cows. However, the authors indicated no effects in terms of feed intake and milk production and composition (except for vitamins A, C, and E).

The effect of silage produced with pomegranate pomace in broiler chicks was evaluated by Gungor et al. [42]. The oxidative status was improved and some effects in the internal morphology were reported in animals consuming the experimental silage. No significant effects were reported for carcass characteristics, the antioxidant defense system, and meat and liver characteristics ( $\mathrm{pH}$ and color).

From these experiments, it seems reasonable to consider that mixing pomace with other components for silage production modifies the microbial activity as well as the characteristics of silage. These effects can be attributed to the composition and content of nutrients (such as water-soluble carbohydrates). It is important to mention that the effect is dependent on the extract composition (apple vs. grape pomace, for instance). 
Additionally, the shift in the fermentation process by using pomace as a raw material in silage production (especially for the production of lactic acid to ethanol) may be reduced from the addition of starter cultures. In terms of animal production, the main benefit seems to be related to animal health and the quality of foods obtained from these animals (chicks, cows, fish, lambs, and pigs), regardless of pomace source. In terms of animal production, the use of either pomace as silage raw material or fermented feed supplement seems to have a negative impact, such as in growth performance. It is worth mentioning that the modification of foods obtained from animals fed with fermented pomace fits in the strategy to naturally enrich foods with nutrients and functional compounds [43]. This strategy is supported by studies with apple [35], grape [38,39], olive and tomato pomaces [40,41]. However, additional studies are still necessary to identify relevant sources due to the controversial results such as those reported for pomegranate pomace in chicken meat [42].

\section{Enzyme Production and Potential Applications}

The use of pomace for the production of enzymes obtained from the agro-industrial processing of foods is an interesting strategy for producing high-added value products (Table 3). One of the main pomaces explored in the production of enzymes is obtained from apple processing. Recent studies point out that apple pomace can be used to obtain different enzymes without an additional carbohydrate source [44-48]. For instance, the production of lignin peroxidase and manganese peroxidase were reported from the fermentation of apple pomace with Phanerochaete chrysosporium BKM-F-1767 [48]. In this study, apple pomace was indicated as the most versatile residue to produce these enzymes in comparison to brewery residue, pulp and paper residue, and fishery waste.

The production of amylase, cellulose, pectinase, and xylanase was reported for fermentation with Rhizopus delemar $\mathrm{F}_{2}$ [44]. Similarly, the production of pectinase was reported in another study carried out with Aspergillus parvisclerotigenus KX928754 where the fermentation was optimized in terms of $\mathrm{pH}$, temperature, and the period of fermentation [45]. Similarly, the combination of two Bacillus strains, Bacillus subtilis and Bacillus pumilus, was indicated as a relevant strategy to produce pectinase from apple pomace [46]. In this study, the authors optimized the fermentation by exploring the effect of solid content and the ratio between B. subtilis and B. pumilus in the production of this enzyme. 
Table 3. Production of enzymes from the fermentation of apple, grape, olive, tomato, orange, pea, and carrot pomaces.

\begin{tabular}{|c|c|c|c|c|}
\hline Source & Microorganism & Fermentation Conditions & Enzyme and Enzymatic Activity & Ref. \\
\hline Apple pomace & Phanerochaete chrysosporium BKM-F-1767 & $\begin{array}{l}40 \text { g substrate, } 60 \% \text { moisture, } \mathrm{pH} 4.5,37^{\circ} \mathrm{C}, \\
\text { and } 14 \text { days }\end{array}$ & $\begin{array}{l}\text { Lignin peroxidase: } 141.4 \mathrm{U} / \mathrm{gds} \\
\text { Manganese peroxidase: } 631.2 \mathrm{U} / \mathrm{gds} \\
\text { Laccase: } 719.9 \mathrm{U} / \mathrm{gds}\end{array}$ & [48] \\
\hline Apple pomace & Aspergillus parvisclerotigenus KX928754 & $\begin{array}{l}5 \mathrm{~g} \text { substrate, } \mathrm{pH} 7.0,168 \mathrm{~h}, 30^{\circ} \mathrm{C}, 2 \% \text { sucrose } \\
\text { and } 3 \% \text { peptone, } 30^{\circ} \mathrm{C} \text {, and } 168 \mathrm{~h}\end{array}$ & Pectinase: $1366.3 \mathrm{U} / \mathrm{mL}$ & [45] \\
\hline Apple pomace & $\begin{array}{l}\text { Bacillus subtilis and Bacillus pumilus ( } 20 \text { and } \\
80 \% \text { in inoculum, respectively) }\end{array}$ & $\begin{array}{l}15 \mathrm{~g} \text { substrate/L, } 0.2 \mathrm{~g} / \mathrm{L} \text { pectin, } 0.2 \mathrm{~g} / \mathrm{L} \\
\mathrm{MgSO}_{4} 7 \mathrm{H}_{2} \mathrm{O} \text {, and } 0.2 \mathrm{~g} / \mathrm{L} \mathrm{K}_{2} \mathrm{HPO}_{4}, \mathrm{pH} 9.0 \text {, } \\
130 \mathrm{rpm}, 30^{\circ} \mathrm{C} \text {, and } 24 \mathrm{~h}\end{array}$ & Pectinase: $11.25 \mathrm{U} / \mathrm{mL}$ & [46] \\
\hline Apple pomace and dahlia tubers & Mucor circinelloides & $\begin{array}{l}10 \mathrm{~g} \text { substrate, apple pomace: dahlia tubers } \\
(9: 1), 83.5 \% \text { moisture, } 0.3 \% \mathrm{NH}_{4} \mathrm{H}_{2} \mathrm{PO}_{4}, 0.2 \% \\
\mathrm{KH}_{2} \mathrm{PO}_{4} \text { and } 0.1 \% \mathrm{KCl}, \mathrm{pH} 6.4,30^{\circ} \mathrm{C}, 5.8 \text { days }\end{array}$ & Inulinase: $411.3 \mathrm{U} / \mathrm{gds}$ & [49] \\
\hline Apple pomace & $\begin{array}{l}\text { Cellulosimicrobium sp. CKMX1 (wild) and } \\
\text { its mutant } \mathrm{E}_{5}\end{array}$ & $\begin{array}{l}10 \mathrm{~g} \text { substrate, } 20 \mathrm{~mL} \text { basal salt medium, } \mathrm{pH} \\
8.0,35^{\circ} \mathrm{C} \text {, and } 72 \mathrm{~h}\end{array}$ & $\begin{array}{l}\text { Xylanase: } 418 \text { (wild) } \\
\left.\text { and } 568 \text { (mutant } E_{5}\right) \mathrm{U} / \mathrm{g}\end{array}$ & [47] \\
\hline Grape pomace & Aspergillus niger NRRL3 & $\begin{array}{l}100 \mathrm{~mL} \text { modified Czapex minimal medium } \\
\text { with grape pomace, } 4 \% \text { tannic acid, pH 5.50, } \\
120 \mathrm{rpm}, 30^{\circ} \mathrm{C}\end{array}$ & Tannase: $3.0-4.5 \mathrm{U} / \mathrm{mL}$ & [50] \\
\hline Grape pomace & Bacillus subtilis natto DSM 17766 & $15 \mathrm{~g} / 100 \mathrm{~mL}, 3 \% \mathrm{H}_{2} \mathrm{SO}_{4}, \mathrm{pH} 6.0$, and 7 days & Cellulase: $0.2 \mathrm{U} / \mathrm{mL}$ & [51] \\
\hline Grape pomace & Pleurotus ostreatus and Pleurotus pulmonarius & $4 \mathrm{~g}, 26^{\circ} \mathrm{C}, 140 \mathrm{rpm}$, and 15 days & $\begin{array}{l}\text { Laccase: } 26.2 \text { and } 15,273.0 \mathrm{U} / \mathrm{g} \text { for } \\
\text { Pleurotus ostreatus and } \\
\text { Pleurotus pulmonarius, respectively }\end{array}$ & [52] \\
\hline Grape pomace and wheat bran & Aspergillus niger 3Т5B8 & $\begin{array}{l}\text { Grape pomace: wheat bran ( } 50 \text { and } 50 \%) \\
60 \% \text { moisture, } 0.91 \% \text { ammonium sulfate } \\
\text { solution, } 37^{\circ} \mathrm{C} \text {, and } 96 \mathrm{~h}\end{array}$ & Tannase: $0.30 \mathrm{U} / \mathrm{g}$ & [53] \\
\hline $\begin{array}{l}\text { White grape pomace, olive mill } \\
\text { wastewater, red grape pomace } \\
\text { and wheat bran }\end{array}$ & Aspergillus niger $\mathrm{B} 60$ & $\begin{array}{l}50 \mathrm{~g} \text { substrate, white grape pomace and olive } \\
\text { mill wastewater, red grape pomace, and wheat } \\
\text { bran }(15,15 \text { and } 70 \% \text { of total substrate, } \\
\text { respectively), } 30^{\circ} \mathrm{C} \text {, and } 120 \mathrm{~h}\end{array}$ & $\begin{array}{l}\text { CMCase: } 668 \mathrm{U} / \mathrm{g} \\
\text { Polygalacturonase: } 3151 \mathrm{U} / \mathrm{g} \\
\text { Amylase: } 1099 \mathrm{U} / \mathrm{g} \\
\text { Xylanase: } 579 \mathrm{U} / \mathrm{g} \\
\text { Protease: } 204 \mathrm{U} / \mathrm{g}\end{array}$ & [54] \\
\hline Olive pomace & Kluyveromyces marxianus & 5 g substrate, $45^{\circ} \mathrm{C}$, and $48 \mathrm{~h}$ & Tannase: $42.4 \mathrm{U} / \mathrm{mg}$ & [55] \\
\hline Exhausted olive pomace & Aspergillus niger CECT 2915 & $10 \mathrm{~g}$ substrate, $30^{\circ} \mathrm{C}$, and 6 days & $\begin{array}{l}\text { Xylanase: } 28 \mathrm{U} / \mathrm{g} \\
\text { Cellulase: } 38 \mathrm{U} / \mathrm{g}\end{array}$ & [56] \\
\hline
\end{tabular}


Table 3. Cont.

\begin{tabular}{|c|c|c|c|c|}
\hline Source & Microorganism & Fermentation Conditions & Enzyme and Enzymatic Activity & Ref. \\
\hline Olive pomace and wheat bran & $\begin{array}{l}\text { Aspergillus ibericus MUM 03.49, Aspergillus } \\
\text { niger MUM 03.58, and Aspergillus } \\
\text { tubingensis MUM } 06.152\end{array}$ & $\begin{array}{l}30 \mathrm{~g} \text { olive pomace: wheat bran ( } 50 \text { and } 50 \% \text { ), } \\
75 \% \text { moisture, } 30^{\circ} \mathrm{C} \text {, and } 7 \text { days }\end{array}$ & $\begin{array}{l}\text { Lipase: } 223,53.6 \text { and } 7.6 \mathrm{U} / \mathrm{g} \text { for } A \text {. } \\
\text { ibericus, A. niger } \\
\text { and } A \text {. tubingensis, respectively }\end{array}$ & [57] \\
\hline Exhausted olive pomace & Crypthecodinium cohnii ATCC 30772 & 5 and $8 \mathrm{~g}$ substrate $/ \mathrm{L}, 27^{\circ} \mathrm{C}, 160 \mathrm{rpm}$, and 7 days & $\begin{array}{l}\text { Pectinase: } 37 \text { and } 33 \mathrm{U} / \mathrm{mL} \text { for } 8 \text { and } \\
5 \mathrm{~g} / \mathrm{L} \text { olive pomace, respectively }\end{array}$ & [58] \\
\hline Tomato pomace & Aspergillus oryzae NRRL 2220 in SSF or SmF & $\begin{array}{l}10 \mathrm{~g} \text { substrate, } 19.8 \mathrm{~g} / \mathrm{L} \text { casein, } 0.92 \mathrm{~g} / \mathrm{L} \mathrm{NaCl}, 30^{\circ} \mathrm{C} \text {, } \\
\text { and } 72 \mathrm{~h}\end{array}$ & $\begin{array}{l}\text { Protease: } 21,309 \text { and } 2343.5 \mathrm{U} / \mathrm{g} \text { for } \\
\text { SSF and SmF, respectively }\end{array}$ & [59] \\
\hline Tomato pomace & Aspergillus oryzae 2220 & $\begin{array}{l}20 \mathrm{~g}, 50 \% \text { initial moisture content, } \mathrm{pH} 6 \text { and } 1 \mathrm{~mL} \text { of } \\
5 \text {-day-old inoculum, } 30^{\circ} \mathrm{C} \text {, and } 72 \mathrm{~h}\end{array}$ & Protease: $12 \mathrm{U} / \mathrm{gds}$ after $42 \mathrm{~h}$ & [60] \\
\hline Tomato pomace & Aspergillus oryzae 2220 (static bioreactor) & $5 \mathrm{~kg}, 10 \mathrm{~cm}$ bed, $30^{\circ} \mathrm{C}$, and $44 \mathrm{~h}$ & Protease: $13.6 \mathrm{U} / \mathrm{gds}$ & [60] \\
\hline Tomato pomace and sorghum stalks & Pleurotus ostreatus and Trametes versicolor & $\begin{array}{l}500 \mathrm{~g} \text { tomato pomace, } 100 \mathrm{~g} \text { sorghum stalks, } \\
\text { and } 28{ }^{\circ} \mathrm{C}\end{array}$ & $\begin{array}{l}\text { Laccase: } 15 \text { and } 35 \mathrm{U} / \mathrm{g} \text { for } P \text {. } \\
\text { ostreatus ( } 4 \text { days) and T. versicolor } \\
\text { (18 days), respectively } \\
\text { Protease: } 13,000 \text { and } 34,000 \mathrm{U} / \mathrm{g} \text { for } \\
\text { P. ostreatus (4 days) and T. versicolor } \\
\text { (13 days), respectively } \\
\text { Xylanase: } 9 \text { and } 50 \mathrm{U} / \mathrm{g} \text { for } P \text {. } \\
\text { ostreatus ( } 4 \text { days) and T. versicolor } \\
\text { (13 days), respectively }\end{array}$ & [61] \\
\hline $\begin{array}{l}\text { Tomato pomace, wheat bran, } \\
\text { and canola meal }\end{array}$ & Bacillus subtilis $\mathrm{T} 4 \mathrm{~b}$ & $\begin{array}{l}\text { Wheat bran } 30 \mathrm{~g} / \mathrm{L} \text {, canola meal } 40 \mathrm{~g} / \mathrm{L} \text {, and tomato } \\
\text { pomace } 15 \mathrm{~g} / \mathrm{L}, 180 \mathrm{rpm}, 28^{\circ} \mathrm{C} \text {, and } 48 \mathrm{~h}\end{array}$ & Xylanase: $315 \mathrm{U} / \mathrm{mL}$ & [62] \\
\hline Orange pomace & Aspergillus niger & 5 g substrate, $30^{\circ} \mathrm{C}$, and $96 \mathrm{~h}$ & $\begin{array}{l}\text { Pectinase: around } 17 \mathrm{U} / \mathrm{g} \\
\text { (endo+exo enzyme activities) }\end{array}$ & [63] \\
\hline Orange pomace & Aspergillus niger (tray bioreactor) & $285 \mathrm{~g}$ substrate/tray, $30^{\circ} \mathrm{C}$, and $96 \mathrm{~h}$ & $\begin{array}{l}\text { Pectinase: around } 60 \mathrm{U} / \mathrm{g} \\
\text { (endo+exo enzyme activities) }\end{array}$ & [64] \\
\hline $\begin{array}{l}\text { Orange pomace } \\
\text { with sugarcane bagasse }\end{array}$ & Aspergillus niger (tray bioreactor) & $285 \mathrm{~g}$ substrate/tray, $30^{\circ} \mathrm{C}$, and $96 \mathrm{~h}$ & $\begin{array}{l}\text { Pectinase: around } 75 \mathrm{U} / \mathrm{g} \\
\text { (endo+exo enzyme activities) }\end{array}$ & [64] \\
\hline Orange pomace & Aspergillus niger (rotating-drum bioreactor) & $285 \mathrm{~g}$ substrate $/ \mathrm{batch}, 30^{\circ} \mathrm{C}$, and $96 \mathrm{~h}$ & $\begin{array}{l}\text { Pectinase: around } 40 \mathrm{U} / \mathrm{g} \\
\text { (endo+exo enzyme activities) }\end{array}$ & [64] \\
\hline Carrot pomace & Penicillium oxalicum BGPUP-4 & $\begin{array}{l}10 \mathrm{~g} \text { substrate, } 90 \% \text { moisture, } 0.5 \% \text { inulin, } \\
0.2 \% \mathrm{NaNO}_{3}, 0.2 \mathrm{~g} / \mathrm{mL} \mathrm{KH}_{2} \mathrm{PO}_{4}, 0.1 \% \mathrm{KCl} \text {, } \\
0.05 \% \mathrm{MgSO}_{4} \cdot 7 \mathrm{H}_{2} \mathrm{O}, 0.001 \% \mathrm{FeSO}_{4} 7 \mathrm{H}_{2} \mathrm{O} \\
\text { and } 0.2 \% \mathrm{NH}_{4} \mathrm{H}_{2} \mathrm{PO}_{4}, \mathrm{pH} 7.0,30^{\circ} \mathrm{C} \text {, and } 4 \text { days }\end{array}$ & Inulinase: $322.10 \mathrm{U} / \mathrm{g}$ & [65] \\
\hline
\end{tabular}

CMCase: carboxymethyl cellulase, SmF: submerged fermentation, and SSF: solid-state fermentation. 
Combining apple pomace with other sources of nutrients can improve enzyme production yields. This factor was considered in the experiment carried out by Singh et al. [49], who used dahlia tuber powder (source of inulin) to produce inulinase with apple pomace. These authors optimized the fermentation in terms of moisture, fermentation period, and $\mathrm{pH}$. Another interesting strategy to obtain extracts rich in enzymes from apple pomace consist in generating mutant strains such as those indicated by Guleria et al. [47]. In this case, the new mutant of Cellulosimicrobium sp. CKMX1 $\mathrm{E}_{5}$ increased the production of xylanase in relation to its parent strain.

Grape is another relevant substrate for the production of enzymes. In this case, the production of tannase was obtained from the fermentation with Aspergillus niger NRRL3 [50]. Similarly, the production of cellulose using Bacillus subtilis was also obtained from the fermentation of grape pomace [51]. Another recent experiment indicated that the production of laccase from grape pomace was dependent on the starter culture [52]. In this case, Pleurotus pulmonarius was more efficient for producing this enzyme than Pleurotus ostreatus. Moreover, the authors also indicated that solid-state fermentation was more appropriate than semiliquid and submerged fermentations.

The effect of adding wheat bran in grape pomace for the production of different enzymes was studied in a recent experiment [53]. The fermentation with Aspergillus niger successfully produced more tannase by combining wheat bran with grape pomace than using only wheat bran. However, the presence of grape pomace limited the production of xylanase and $\beta$-glucosidase and slowed the production of polygalacturonase. Additionally, the authors also reported a dependency on time for the production of polygalacturonase and carboxymethyl cellulase (higher enzymatic yields were obtained after $96 \mathrm{~h}$ of fermentation). Additionally, Papadaki et al. [54] reported the production of amylase, carboxymethyl cellulase, polygalacturonase, protease, and xylanase from a substrate composed of white grape pomace, olive mill wastewater, red grape pomace and wheat bran. Aspergillus niger was used to obtain these enzymes.

Olive processing for oil extraction also generates a valuable substrate for microbial enzyme production. For instance, a recent experiment with olive pomace indicated that tannase could be obtained from the fermentation with Kluyveromyces marxianus [55]. Another relevant example that supports the use of this pomace in the production of enzymes is the study carried out by Leite et al. [56]. In this case, the authors fermented the exhausted olive pomace with Aspergillus niger and reported the production of xylanase and cellulose. In the case of lipase production from grape pomace, the effect of Aspergillus species was evaluated in a recent study [57]. Aspergillus ibericus was a more efficient species in relation to Aspergillus niger and Aspergillus tubingensis. Interestingly, a related experiment with exhausted olive pomace reported the production of pectinase from the growth of the microalgae Crypthecodinium cohnii [58]. Additionally, no significant differences in terms of substrate concentration ( $5 \mathrm{vs} .8 \mathrm{~g} / \mathrm{L}$ ) in the production of this enzyme were reported.

Tomato is another relevant source of pomace that can be utilized in the production of enzymes. Proteases could be obtained from tomato pomace using Aspergillus oryzae according to recent studies [59,60]. Moreover, the study carried out by Belmessikh et al. [59] indicated that the production of protease from tomato pomace was more efficient in solidstate rather than submerged fermentation. The optimization also indicated that casein and $\mathrm{NaCl}$ levels are significant factors in improving the production of protease.

The combination of tomato pomace with other sources of nutrients for enzymatic production has also been explored [61]. Particularly, for the combination with sorghum stalks, the production in a laccase, protease, and xylanase were dependent on the starter culture [61]. In this case, Pleurotus ostreatus was associated with a faster but less intense production of these enzymes. Conversely, Trametes versicolor had higher production yields but after longer fermentation periods. Another more recent experiment with tomato pomace, wheat bran, and canola meal indicated that the fermentation with Bacillus subtilis was associated with high xylanase content [62]. 
Another relevant pomace for the production of enzymes is obtained from orange processing. In this case, recent experiments explored the generation of pectinase from the fermentation with Aspergillus niger [63,64]. It is also relevant to comment that a recent experiment indicated that the use of sugarcane bagasse is a relevant strategy to reduce moisture loss during fermentation and improve the production yield of pectinase from orange pomace [64]. In a similar way, carrot pomace was indicated as an interesting substrate for fermentation, which can be utilized in the production of inulinase [65]. The production of inulinase was affected by moisture content, fermentation period, and $\mathrm{pH}$.

The production of enzymes from pomaces can also be improved by the use of emerging technologies such as microwave heating and ultrasound. This aspect was reported in the production of carbohydrases from apple pomace by Pathania et al. [44]. According to these authors, the intensity of microwaves (as a pre-treatment) had a significant effect on the production yield. The maximum values for amylase, pectinase, and xylanase were reported for the $450 \mathrm{~W}$ treatment. Additional power (up to $600 \mathrm{~W}$ ) caused a reduction in the production of enzymes. In the same line of thought, the use of ultrasound can improve the production of enzymes. Leite et al. [56] indicated that using $750 \mathrm{~W}$ and $20 \mathrm{kHz}$ and optimizing the time and liquid/solid ratio (12.4 min and 7.3) maximized the production yields of xylanase $(75 \mathrm{U} / \mathrm{g})$ and cellulase $(35 \mathrm{U} / \mathrm{g})$.

It is also important to highlight that some experiments to scale up the production of enzymes from pomaces have been carried out in the last decade. One relevant example that explored this aspect was performed by Boukhalfa-lezzar et al. [60] with tomato pomace fermented with Aspergillus oryzae. In this study, similar production yields were reported between lab scale and a bioreactor for protease production $(12 \mathrm{U} / \mathrm{gds}$ after $42 \mathrm{~h}$ with $20 \mathrm{~g}$ of substrate vs. $13.6 \mathrm{U} / \mathrm{gds}$ after $44 \mathrm{~h}$ with $5 \mathrm{~kg}$ of substrate). Another relevant experiment supporting the increase in the production scale of enzymes was carried out with orange pomace in a tray reactor and a rotating-drum reactor [64]. In this case, differences in production yield were reported between these two reactors wherein the bioreactor with trays had the highest yield. Moreover, both reactors increased the production of pectinase in relation to a previous experiment from the same research group [63].

The purification of enzymes obtained from fermentation is another relevant aspect considered in recent studies. In order to explore potential solutions to improve the separation of enzymes, an experiment with lignin peroxidase and manganese peroxidase explored the use of centrifugation and filtration after the fermentation of apple pomace [48]. The results revealed that centrifugation was more efficient for separating both enzymes than filtration. A recent study compared the use of fractionation with ammonium sulfate and chromatography filtration in the purification of tannase from fermented olive pomace [55]. Both methods led to extracts with increased enzymatic activity wherein the chromatography filtration was more efficient than fractionation with ammonium sulfate (1026.1 vs. $664 \mathrm{U} / \mathrm{mg}$, respectively). A similar outcome was obtained in another study with pectinase from apple pomace ( $1081.7 \mathrm{vs.} 860.6 \mathrm{U} / \mathrm{mg}$ for chromatography filtration and ammonium sulfate fractionation, respectively) [45].

Potential applications can also be considered in the context of enzyme production. Since pomace is a by-product from food processing, the use of these enzymes in food production can be suggested. A relevant example is the experiment carried out by Mahmoodi et al. [63]. In this study, cubic pieces of fresh apple were treated with pectinase to produce apple juice. The main effects were the reduction in juice viscosity and increased juice yield, soluble sugar content, and pectate content. A similar experiment with polygalacturonase obtained from apple pomace was efficient for clarifying apple juice [66].

An interesting application for enzymes obtained from pomace fermentation is the detoxification of food. This approach was evaluated by Cuprys et al. [67] who applied laccase from apple fermentation with Trametes versicolor to decompose ciprofloxacin (an antibiotic). However, the presence of a reducing agent (syringaldehyde in this study) was necessary to favor the enzymatic degradation of this antibiotic in water. Although the scientific information about the application of microbial enzymes from pomace fermentation 
in food processing is limited, the use of these enzymes could be considered to improve the processing of beer, bread, cheese, syrup, and wine [68] in further experiments. Moreover, potential applications in other research areas are in pharmaceutical, chemical, fuel, and paper production [69].

The use of pomace from different sources can be seen as a relevant strategy to favor the production of enzymes. Current scientific evidence indicates that the production of enzymes can be improved by adding complementary sources of nutrients (such as ingredients rich in carbohydrates for pomaces with reduced levels of this nutrient), applying emerging technologies to favor the exposure of substrates, and increasing the scale of production (minimal effect in production yield, to some extent). The purification with different techniques can also be applied and support the progression towards application in other industrial processes.

\section{Release and Production of Bioactive Compounds}

Improving the biological activity of pomace from food processing is one of the potential and emerging applications of fermentation. This strategy has been applied to obtain carotenoids, fatty acids, $\gamma$-linolenic acid, and polyphenols (Table 4). Polyphenols are an important class of bioactive compounds that are found in pomaces. From a broad perspective, polyphenols can be found either in free or bound forms. Polyphenols in free form are those present in the cytosol of vegetable cells, whereas the bound polyphenols are those bound to cell wall constituents [70]. For bound polyphenols in particular, their extraction is complex and conventional extraction methods have low efficiency to separate these compounds from structural components of food. In this context, the use of fermentation (by means of the action of microbial enzymes) has been indicated as a relevant strategy to recovery this compound $[70,71]$.

Table 4. Bioactive compounds obtained from pomace fermentation.

\begin{tabular}{|c|c|c|c|c|}
\hline Source & Fermentation Conditions & Bioactive Compounds & Outcome & Ref. \\
\hline Grape pomace & $\begin{array}{l}2 \text { g substrate, Rhizomucor miehei NRRL 5282, } \\
37^{\circ} \mathrm{C} \text {, and } 18 \text { days }\end{array}$ & Polyphenols & $\begin{array}{l}\text { Oven dried: reduction in TPC and FRAP, no } \\
\text { effect in DPPH } \\
\text { Lyophilized: maximum TPC and FRAP } \\
\text { values at day } 7, \text { no effect in DPPH }\end{array}$ & [72] \\
\hline Grape pomace & $\begin{array}{l}10 \text { g substrate (grape pomace:wheat bran; } \\
1: 1 \text { ), Aspergillus niger } 3 \mathrm{~T} 5 \mathrm{~B} 8,37^{\circ} \mathrm{C} \text {, and } 96 \mathrm{~h}\end{array}$ & Polyphenols & Increased TPC, ABTS, and ORAC & [53] \\
\hline Grape pomace & $\begin{array}{l}50 \mathrm{~g} \text { substrate, Trametes versicolor TV-6, } \\
5 \text { mycelial plugs, } 27^{\circ} \mathrm{C} \text {, and } 15 \text { days }\end{array}$ & Polyphenols & $\begin{array}{l}\text { Reduced 5-lipoxygenase and hyaluronidase } \\
\text { activities (up to } 4 \text { days of fermentation), } \\
\text { and polyphenol content throughout } \\
\text { fermentation period }\end{array}$ & [74] \\
\hline Grape pomace & $\begin{array}{l}60 \mathrm{~g} \text { substrate, Actinomucor elegans ATCC- } \\
22963 \text { or Umbelopsis isabellina ATCC-36671, } \\
30^{\circ} \mathrm{C} \text {, and } 12 \text { days }\end{array}$ & $\begin{array}{l}\gamma \text {-Linolenic acid } \\
\text { and carotenoids }\end{array}$ & $\begin{array}{l}\gamma \text {-Linolenic acid: maximum at } 4 \text { days for } \\
\text { Umbelopsis isabellina and } 6 \text { days for } \\
\text { Actinomucor elegans } \\
\text { Carotenoids: carotene increased throughout } \\
\text { fermentation and maximum at } 8 \text { days } \\
\text { for lutein }\end{array}$ & [73] \\
\hline Apple pomace & $\begin{array}{l}2 \mathrm{~g} \text { substrate, Rhizomucor miehei NRRL 5282, } \\
37^{\circ} \mathrm{C} \text {, and } 18 \text { days }\end{array}$ & Polyphenols & $\begin{array}{l}\text { Oven dried: reduced TPC, maximum FRAP } \\
\text { value at day } 3 \text {, no effect in DPPH } \\
\text { Lyophilized: slight increase in TPC and } \\
\text { DPPH up to day } 10 \text {, maximum FRAP value } \\
\text { at day } 10\end{array}$ & [72] \\
\hline Apple pomace & $12.5 \mathrm{~g}$, natural fermentation, $30^{\circ} \mathrm{C}$, and $72 \mathrm{~h}$ & Polyphenols & $\begin{array}{l}\text { Reduced throughout } \\
\text { the fermentation period }\end{array}$ & [75] \\
\hline Apple pomace & $\begin{array}{l}250 \text { g substrate, Saccharomyces cerevisiae ref: } \\
32 \text {, Saccharomycodes bayanus ref: C } 6 \text {, and } \\
\text { Hanseniaspora uvarum ref: } 62,25^{\circ} \mathrm{C} \text {, } \\
\text { and } 7 \text { days }\end{array}$ & $\begin{array}{l}\text { Fatty acids } \\
\text { and polyphenols }\end{array}$ & $\begin{array}{l}\text { Increased fatty acids } \\
\text { Slight reduction in polyphenols }\end{array}$ & [76] \\
\hline Apple pomace & $\begin{array}{l}40,60 \text { and } 80 \mathrm{~g} \text { substrate } / \mathrm{L}, \\
\text { Yarrowia lipolytica, } 28^{\circ} \mathrm{C} \text {, and } 6 \text { days }\end{array}$ & Fatty acids & Maximum production after day 3 & [77] \\
\hline $\begin{array}{l}\text { Elderberry and dwarf } \\
\text { elderberry pomace }\end{array}$ & $\begin{array}{l}50 \mathrm{~g} \text { substrate, Aspergillus niger ATCC-6275, } \\
30^{\circ} \mathrm{C} \text {, and } 6 \text { days }\end{array}$ & $\begin{array}{l}\text { Polyphenols and } \\
\text { fatty acids }\end{array}$ & $\begin{array}{l}\text { TPC: maximum release } \\
\text { up to 3-4 days of fermentation } \\
\text { DPPH: maximum after 3-4 days of } \\
\text { fermentation } \\
\text { Lipids: slight increase in linoleic and oleic } \\
\text { acids up to } 4 \text { days of fermentation }\end{array}$ & [78] \\
\hline Olive pomace & $\begin{array}{l}5 \text { g substrate, Kluyveromyces marxianus } \\
\text { NRRL Y-8281, } 45^{\circ} \mathrm{C} \text {, and } 48 \mathrm{~h}\end{array}$ & Tannic and gallic acids & $\begin{array}{l}\text { Reduced tannic acid and increased gallic } \\
\text { acid content }\end{array}$ & [79] \\
\hline Exhausted olive pomace & $\begin{array}{l}5 \text { and } 8 \text { g substrate } / \mathrm{L}, \text { Crypthecodinium } \\
\text { cohnii ATCC } 30772,27^{\circ} \mathrm{C} \text {, } \\
160 \mathrm{rpm} \text {, and } 7 \text { days }\end{array}$ & Fatty acids & $\begin{array}{l}\text { Increased total lipid and DHA content in } \\
\text { dry cells }\end{array}$ & [58] \\
\hline
\end{tabular}


Table 4. Cont.

\begin{tabular}{|c|c|c|c|c|}
\hline Source & Fermentation Conditions & Bioactive Compounds & Outcome & Ref. \\
\hline Exhausted olive pomace & $\begin{array}{l}25 \text { g substrate/L, Crypthecodinium cohnii } \\
\text { ATCC } 30772,27^{\circ} \mathrm{C}, 160 \mathrm{rpm} \text {, and } 5 \text { days }\end{array}$ & Fatty acids & $\begin{array}{l}\text { High production yield; negative effect of } \\
\text { detoxification prior to fermentation }\end{array}$ & [80] \\
\hline Chokeberry pomace & $\begin{array}{l}40 \text { g substrate, Aspergillus niger ATCC- } 6275 \\
\text { or Rhizopus oligosporus ATCC-22959, } 30^{\circ} \mathrm{C} \text {, } \\
\text { and } 12 \text { days }\end{array}$ & Polyphenols & $\begin{array}{l}\text { TPC: maximum at } 6 \text { days for } \\
\text { or Rhizopus oligosporus and } 9 \text { days for } \\
\text { Aspergillus niger; DPPH and TEAC: } \\
\text { maximum at } 6 \text { days for Aspergillus niger } \\
\text { and } 9 \text { days for Rhizopus oligosporus }\end{array}$ & [81] \\
\hline Plum pomace & $\begin{array}{l}15 \text { g substrate, Aspergillus niger ATCC- } 6275 \\
\text { or Rhizopus oligosporus ATCC- } 22959,30^{\circ} \mathrm{C} \text {, } \\
\text { and } 14 \text { days }\end{array}$ & Polyphenols & $\begin{array}{l}\text { TPC: maximum after } 9 \text { days of fermentation; } \\
\text { DPPH: maximum at } 6 \text { days of fermentation }\end{array}$ & [82] \\
\hline Apricot pomace & $\begin{array}{l}15 \mathrm{~g} \text { substrate, Aspergillus niger ATCC- } 6275 \\
\text { or Rhizopus oligosporus ATCC-22959, } 30^{\circ} \mathrm{C} \text {, } \\
\text { and } 14 \text { days }\end{array}$ & Polyphenols & $\begin{array}{l}\text { TPC: maximum at } 9 \text { days for Rhizopus } \\
\text { oligosporus; reduced after } 6 \text { days for } \\
\text { Aspergillus niger; DPPH: maximum at } 2 \text { days } \\
\text { for both }\end{array}$ & [83] \\
\hline Pitahaya pomace & $\begin{array}{l}2 \text { g substrate, Rhizomucor miehei NRRL 5282, } \\
37^{\circ} \mathrm{C} \text {, and } 18 \text { days }\end{array}$ & Polyphenols & $\begin{array}{l}\text { Oven dried: slight decrease in TPC, } \\
\text { decreased FRAP, and no effect in DPPH } \\
\text { Lyophilized: slight increase in TPC, } \\
\text { maximum FRAP value at day } 10 \text { and DPPH } \\
\text { value at day } 15\end{array}$ & [72] \\
\hline Red bayberry pomace & $\begin{array}{l}0.02 \% \text { live yeast, } 25^{\circ} \mathrm{C}, 16 \mathrm{~h} \text { followed } \\
\text { by } 0.1 \% \text { probiotic mix, } 28^{\circ} \mathrm{C}, 24 \mathrm{~h} \text {, and let } \\
\text { for up to } 7 \text { days }\end{array}$ & Polyphenols & $\begin{array}{l}\text { Increased TPC and TFC values; reduced } \\
\text { DPPH value }\end{array}$ & [84] \\
\hline
\end{tabular}

DHA: Docosahexanoic acid, DPPH: (2,2-diphenyl-1-picrylhydrazyl) free radical, FRAP: ferric reducing antioxidant power, ORAC: oxygen radical absorbance capacity, TEAC: trolox equivalent antioxidant capacity, TFC: total flavonoid content, and TPC: total polyphenol content.

For instance, studies carried out with grape pomace indicate that polyphenols [53,72], $\gamma$-linolenic acid and carotenoids [73] can be obtained from fermentation. In addition to the characterization of the content of these bioactive compounds, these studies also revealed aspects related to the preparation of samples, fermentation period, and the effect of the starter culture.

Regarding the effects of sample preparation and fermentation period in the release of polyphenols, a recent experiment indicated that lyophilization is a better pre-treatment than oven-drying to improve the extraction of polyphenols from grape pomace [72]. Moreover, this study also indicated that long fermentation periods do not favor the accumulation of polyphenols. Additionally, this effect could be explained by the instability of free polyphenols during fermentation. The gradual decomposition of free polyphenols can occur, which may be compensated by the release of bound polyphenols from microbial activity. Another related study with pomace supports this consideration and the necessity to define the optimum fermentation period. The high polyphenol and bioactivity in the beginning of the fermentation period were followed by the reduction in both indicators (polyphenol content and biological activity) as fermentation progressed up to 15 days [74]. Additionally, Teles et al. [53] reported increasing polyphenol content and antioxidant activity during the fermentation of grape pomace with Aspergillus niger during a shorter period $(96 \mathrm{~h})$ in relation to these aforementioned studies. This study also indicated that polyphenol content was positively correlated with antioxidant potential.

The production of $\gamma$-linolenic acid and carotenoids by solid-state fermentation also displayed the same dependency on fermentation time, wherein maximum yields were obtained after 6 days of fermentation [73]. In the case of carotenoids, the synthesis of lutein had a maximum yield after 8 days, whereas the production of carotene increased throughout the fermentation period (18 days).

Apple pomace has also been explored as a relevant source of polyphenols and fatty acids. For instance, the effect of pre-treatment and fermentation on polyphenol accumulation during fermentation was studied by Zambrano et al. [72]. The maximum polyphenol content was not affected by the pretreatment (lyophilization vs. over-drying), but significant changes were reported during the fermentation period. The maximum polyphenol yield and antioxidant potential were obtained at day 10. Conversely, Lohani and Muthukumarappan [75] reported a gradual reduction in the polyphenol content of naturally fermented apple pomace. Madrera et al. [76] reported a slight reduction in the polyphenol content of fermented apple pomace with different yeasts. Additionally, this study also indicated that the production of fatty acids can be obtained from the fermentation of apple 
pomace with yeasts. An interesting experiment with apple pomace explored the production of fatty acids in a $5 \mathrm{~L}$ bioreactor [77]. In this case, different concentrations of apple pomace were used as a carbon source for lipid biosynthesis. A concentration-dependent effect (40, 60 and $80 \mathrm{~g}$ substrate/L) in the production of fatty acids was reported. Moreover, the maximum yield for each tested apple pomace concentration was achieved in a short period (3 days).

In the case of olive pomace, the fermentation with Kluyveromyces marxianus led to a reduction in tannic acid content and an increase in the concentration of its depolymerized form, gallic acid [79]. Another interesting application of exhausted olive pomace (residue obtained after the removal of residual oil from olive pomace) is the production of microbial fatty acids, especially docosahexaenoic acid (DHA). A recent experiment indicated that the concentration of exhausted olive pomace had a concentration-dependent effect in the production of DHA by the microalgae Crypthecodinium cohnii [58]. Interestingly, another study with the same microalga revealed that detoxification with activated carbon reduced the production of fatty acids [80].

The simultaneous production of polyphenols and fatty acids from fruit pomace was also explored in a recent study with two Sambucus species [78]. In these fruits, optimum polyphenol production yield and antioxidant activity were obtained at day 3 and 4 (regardless of species), respectively. A similar effect was observed for the accumulation of linoleic and oleic fatty acids, which had maximum values at day 4 . Similarly, the accumulation of polyphenols and antioxidant activity during the fermentation of chokeberry pomace were dependent on the time and starter culture [81]. Maximum values for total phenolic content were obtained between day 6 and 9 of fermentation for Rhizopus oligosporus and 9 days for Aspergillus niger.

Studies carried out with plum [82] and apricot [83] pomaces indicated that optimum fermentation periods for polyphenol accumulation and antioxidant activity from Aspergillus niger fermentation were 9 and 6 days, respectively. Another recent experiment indicated that the accumulation of polyphenols in pitahaya pomace from the activity of Rhizomucor miehei was improved by lyophilizing samples before fermentation [72]. A related experiment evaluated the accumulation of polyphenols and antioxidant activity in red bayberry pomace during 7 days during the sequential fermentation with Saccharomyces cerevisiae and a mix of lactic acid bacteria (Lactobacillus bulgaricus, Bifidobacterium lactis, and other lactic acid bacteria) [84]. A gradual increase in the polyphenol content was reported throughout the 7 days of fermentation. Moreover, the antioxidant activity of fermented pomace after this period was improved in relation to non-fermented pomace.

Since the fermentation of pomaces can lead to high polyphenol content and antioxidant activity (Table 4), the biological response to the consumption of fermented pomace was also explored in recent studies. Improvements in the antioxidant defense system and a reduction in the oxidative status of liver and ilium in mice fed with fermented blueberry pomace were reported [85]. The intestine inflammatory response (tumor necrosis factor-alpha and interleukin-10) was also improved in animals that consumed the diet supplemented with fermented blueberry pomace. Concentration-dependent effects were observed in the antioxidant and anti-inflammatory activities. Moreover, these effects ameliorated the modifications induced by a high-fat diet in terms of antioxidant and anti-inflammatory responses.

A further experiment carried out by the same research group explored the functional effect of fermented blueberry pomace in indicators of gut health of mice [86]. The consumption of supplemented diets improved the gut immunological response (secretory immunoglobulin A), affected the gut microbiota and also favored the production of butyric acid (a short fatty acid associated with health benefits). Again, the supplemented diet ameliorated the modifications induced by a high-fat diet in the gut immunological response and gut health. Another experiment in vivo that supports the health benefits associated with the fermentation of pomaces was carried out by Yan et al. [87]. In this case, the consumption of fermented blueberry pomace (rich in polyphenols) improved the resistance to fatigue in relation to control animals that ingested sterile water. 
Along with the production of fermented pomaces with increased biological activity, it is also important to develop strategies to isolate active components from the bulk of fermented pomace. This aspect was recently explored by Espinosa-Pardo et al. [88] who optimized the extraction of polyphenols with super-critical $\mathrm{CO}_{2}$ and co-solvents. The authors indicated that the extraction with $\mathrm{CO}_{2}\left(25 \mathrm{MPa}\right.$ at $\left.60{ }^{\circ} \mathrm{C}\right)$ and $90 \%$ ethanol as co-solvent was the most efficient extraction condition to obtain the highest polyphenol content and antioxidant activity. Another important aspect to consider is the effect of digestion in the stability of active compounds. Yan et al. [87] evaluated the impact of simulated digestion and indicated significant reduction in the polyphenol content and antioxidant activity of blueberry pomace fermented by Lactobacillus rhamnosus GG and Lactobacillus plantarum-1 (1:1).

The fermentation of pomaces can be seen as a relevant strategy to produce functional supplements with interesting biological effects, especially from berries. However, additional advances, especially in the application of extraction technologies and the characterization of biological effects in vivo, are still necessary.

\section{Production of Organic Acids}

Organic acids are multipurpose compounds that have been applied in animal production [89], food processing [90], cosmetic preservation [91] and battery recycling [92], for instance. Due to their importance and the current trends to improve sustainability within the organic acid production sector, several studies have been carried out to explore the use of pomaces in the production of high-added value compounds (Table 5). One relevant example of this strategy is the study performed by Vashisht et al. [93] who evaluated the production of acetic acid using Acetobacter pasteurianus SKYAA25 from apple pomace. These authors indicated that the production of acetic acid was affected by the temperature $\left(37^{\circ} \mathrm{C}\right)$, concentration of bioethanol $(8 \%$, produced from the same strain), and apple pomace $(2 \%)$ in fermentation media. Similarly, the production of acetic acid from the fermentation of apple pomace was reported in another study using Acetobacter aceti [94].

Table 5. Organic acids produced from pomace fermentation.

\begin{tabular}{|c|c|c|c|}
\hline Source & Fermentation Conditions & Organic Acid and Yield & Ref. \\
\hline Apple pomace & $\begin{array}{l}120 \mathrm{~g} \text { substrate } / \mathrm{L}, \text { Acetobacter } \\
\text { pasteurianus, } 37^{\circ} \mathrm{C}, 180 \mathrm{rpm}, \\
\text { and } 24 \mathrm{~h}\end{array}$ & Acetic acid: $52.4 \mathrm{~g} / 100 \mathrm{~g} \mathrm{DM}$ & [93] \\
\hline Apple pomace & $\begin{array}{l}\text { 1.5 L of substrate, Acetobacter aceti, } \\
\text { pH } 7.0,28^{\circ} \mathrm{C} \text {, and } 7 \text { days }\end{array}$ & Acetic acid: $61.4 \mathrm{~g} / 100 \mathrm{~g} \mathrm{DM}$ & [94] \\
\hline Apple pomace & $\begin{array}{l}14 \mathrm{~g} \text { substrate } / 100 \mathrm{~g} \text {, } \\
\text { Propionibacterium freudenreichii, } 37^{\circ} \mathrm{C} \text {, } \\
\text { and } 120 \mathrm{~h}\end{array}$ & Propionic acid: 38 g/100 g DM & [95] \\
\hline Apple pomace & $\begin{array}{l}250 \mathrm{~mL} \text { substrate, Propionibacterium } \\
\text { freudenreichii, } 37^{\circ} \mathrm{C} \text {, and } 120 \mathrm{~h}\end{array}$ & $\begin{array}{l}\text { Acetic acid: } 5.01 \mathrm{~g} / \mathrm{L} \\
\text { Propionic acid: } 14.54 \mathrm{~g} / \mathrm{L}\end{array}$ & [96] \\
\hline Apple pomace & $\begin{array}{l}25 \mathrm{~g} \text { substrate, Aspergillus ornatus } \\
\text { and Alternaria alternate, } \mathrm{pH} 5.0 \text {, } \\
30^{\circ} \mathrm{C} \text {, and } 48 \mathrm{~h}\end{array}$ & Citric acid: $0.5 \mathrm{~g} / \mathrm{L}$ & [97] \\
\hline Apple pomace & $\begin{array}{l}25 \text { g substrate, Rhizopus oryzae, } 30^{\circ} \mathrm{C} \text {, } \\
\text { and } 14 \text { days }\end{array}$ & Fumaric acid: $52 \mathrm{~g} / \mathrm{kg}$ & [98] \\
\hline Apple pomace & $\begin{array}{l}\text { 3-4 L working volume, } 50 \% \\
\text { moisture, Rhizopus oryzae, } 1.97 \mathrm{~atm} \text {, } \\
\text { and } 14 \text { days }\end{array}$ & Fumaric acid: $138 \mathrm{~g} / \mathrm{kg}$ & [99] \\
\hline
\end{tabular}

Piwowarek et al. [95] studied the optimization of the production of propionic acid from apple pomace fermentation with Propionibacterium freudenreichii T82. According to these authors, the accumulation of propionic acid was increased due to a better control of the fermentation process, i.e., adding biotin to fermentation media, carrying out the $\mathrm{pH}$ control at 24 and $48 \mathrm{~h}$ of fermentation, and increasing the nitrogen level (supplementing the apple pomace with peptone). However, no significant effects were obtained for the variations in temperatures from 30 to $37^{\circ} \mathrm{C}$. In another study from the same research 
group with apple pomace, the effect of supplementation (potato wastewater, yeast extract, and peptone) to increase the production yield of propionic acid was evaluated [96]. The use of yeast extract and peptone in apple pomace in the fermentation medium improved the propionic acid yield to a maximum of $14.54 \mathrm{~g} / \mathrm{L}$ after $120 \mathrm{~h}$ of fermentation with Propionibacterium freudenreichii. Additionally, the production of acetic acid was also evaluated in this study. A continuous increase in the accumulation of this acid was reported until the end of the fermentation period $(120 \mathrm{~h})$ and the most efficient supplement for apple pomace was potato wastewater (maximum yield of $5.01 \mathrm{~g} / \mathrm{L}$ ).

Apple pomace can also be fermented to produce citric acid [97]. In this case, a recent experiment explored the effect of temperature, $\mathrm{pH}$, and substrate amount in the fermentation batch with the combination of Aspergillus ornatus and Alternaria alternate. The $\mathrm{pH}$ and temperature had optimum values of 5 and $30^{\circ} \mathrm{C}$, respectively. Increasing the substrate caused a significant increase in the production of citric acid, which led to choosing the maximum substrate amount tested in this study ( $25 \mathrm{~g})$. Additionally, supplementing the apple pomace with arginine favored the production of citric acid (maximum yield of $2.7 \mathrm{~g} / \mathrm{L}$ ).

Another relevant acid produced from pomaces is the fumaric acid. The production of this acid with Rhizopus oryzae was dependent on the fermentation time [98]. The maximum yield was reported after 14 days $(52 \mathrm{~g} / \mathrm{kg}$ ) and no additional increase was observed at up to 21 days of fermentation. The production of fumaric acid using the same microorganism and pomace was also explored in a bench scale fermenter [99]. The system comprised by a rotary drum increased the production of fumaric acid to $138 \mathrm{~g} / \mathrm{kg}$ within the same fermentation period (14 days).

\section{Production of Bioflavors}

The production of high-added value compounds from pomaces has also been shown to produce bioflavors. The production of aromas from apple pomace fermentation was explored in a recent experiment with yeasts (Hanseniaspora uvarum, Hanseniaspora valbyensis, and Saccharomyces cerevisiae) [100]. This study indicated a strain-dependent effect in the formation of volatile compounds wherein the use of Saccharomyces cerevisiae led to a bigger accumulation of volatile fatty acids and their respective ethyl esters, whereas the fermentation with Hanseniaspora strains favored the generation of volatile acetic acid esters. A related study evaluated the effect of fermented pomace in a volatile composition of beer [101]. In this case, apple pomace was fermented with lactic acid bacteria (Lactobacillus rhamnosus 1473 and 1019, and Lactobacillus casei 2246) and significant differences were reported among volatile compositions of apple pomace. However, the fermented pomace (Lactobacillus rhamnosus 1473) led to slight modifications in the volatile composition (particularly for ketones and alcohols) of beer. The production of bioflavors was also explored using Lacticaseibacillus rhamnosus to ferment orange pomace [102]. This study revealed that fermented pomace had floral (citronellyl formate, 1-nonanol, and $\beta$-linalool), citrus (citral and limonene), fruity ( $\beta$-cyclocitral and benzaldehyde), herbaceous (1-hexanol), bready and caramelly (furfural), and spice (eugenol and carveol) notes.

Finally, another aspect to be considered in the context of the utilization of high-added value compounds obtained from the fermentation/biotransformation of pomaces is their safety. Mycotoxins and pesticides are relevant contaminants in the peels of fruits that may persist in pomaces [103-105]. The effect of fermentation to decontaminate fruits and pomaces is still poorly studied.

\section{Conclusions}

The use of fermentation/biotransformation to obtain high-added value compounds is a valuable solution to improve the reutilization of pomaces from the food industry. The advances in incorporating and optimizing the use of pomaces in animal feed by generating silages and feeds that improve animal health is a relevant alternative to using fermented pomaces. Growth performance can be affected, whereas animal health status can be 
improved. The absence of negative effects and the improvement in the nutritional quality of the foods obtained from animals fed with fermented pomaces is another favorable characteristic to support this strategy.

In terms of industrial processes, the production of high-added value products (especially from grape, apple, and olive) such as enzymes and organic acids for application in food processing as well as in other areas is a relevant application. The release of bound phenolics for the development of functional foods (supported by studies in vitro and in vivo), the synthesis of carotenes and fatty acids, and the production of volatile compounds to improve the aroma of food products are potential applications.

One of the main limitations in terms of industrial application consists of its current poor incorporation into other processing chains. Extraction and purification technologies can be seen as current bottlenecks to strengthening the connections between the pomace generation in food industries and their incorporation into other productions chains. In this sense, further studies could aim to explore strategies to improve the isolation of high-added value compounds. Additional studies are still necessary to define strategies to apply the high-added value compounds obtained from pomaces from fermentation/biotransformation in the development of food products. Studies about the detoxification and reduction of potential health risks associated with mycotoxins and pesticides are necessary.

Author Contributions: Conceptualization, P.E.S.M., M.P., R.D. and J.M.L.; writing—original draft preparation, P.E.S.M., M.P. and R.D.; writing—review and editing, M.P., R.D., A.N., C.H. and N.W.; supervision, J.M.L. All authors have read and agreed to the published version of the manuscript.

Funding: This research received no external funding.

Institutional Review Board Statement: Not applicable.

Informed Consent Statement: Not applicable.

Data Availability Statement: Not applicable.

Acknowledgments: Thanks to GAIN (Axencia Galega de Innovación) for supporting this publication (grant number IN607A2019/01).

Conflicts of Interest: The authors declare no conflict of interest.

\section{References}

1. Bordiga, M.; Travaglia, F.; Locatelli, M. Valorisation of grape pomace: An approach that is increasingly reaching its maturity-A review. Int. J. Food Sci. Technol. 2019, 54, 933-942. [CrossRef]

2. Gassara, F.; Brar, S.K.; Pelletier, F.; Verma, M.; Godbout, S.; Tyagi, R.D. Pomace waste management scenarios in Québec-Impact on greenhouse gas emissions. J. Hazard. Mater. 2011, 192, 1178-1185. [CrossRef]

3. Difonzo, G.; Troilo, M.; Squeo, G.; Pasqualone, A.; Caponio, F. Functional compounds from olive pomace to obtain high-added value foods-A review. J. Sci. Food Agric. 2021, 101, 15-26. [CrossRef] [PubMed]

4. Perussello, C.A.; Zhang, Z.; Marzocchella, A.; Tiwari, B.K. Valorization of Apple Pomace by Extraction of Valuable Compounds. Compr. Rev. Food Sci. Food Saf. 2017, 16, 776-796. [CrossRef]

5. Jin, Q.; Wang, Z.; Feng, Y.; Kim, Y.T.; Stewart, A.C.; O’Keefe, S.F.; Neilson, A.P.; He, Z.; Huang, H. Grape Pomace And Its Secondary Waste Management: Biochar Production for a Broad Range of Lead (Pb) Removal From Water. Environ. Res. 2020, 186, 109442. [CrossRef]

6. IMARC Fruit Juice Market Size, Share, Trends \& Forecast 2021-2026. Available online: https://www.imarcgroup.com/fruit-juicemanufacturing-plant (accessed on 13 October 2021).

7. Statista Inc. Juices-Worldwide. Available online: https://www.statista.com/outlook/cmo/non-alcoholic-drinks/juices/ worldwide (accessed on 13 October 2021).

8. European Commission EU Agricultural Outlook 2019-30: Olive Oil Consumption to Rise in Non-Producing EU Countries. Available online: https:/ / ec.europa.eu/info/news/eu-agricultural-outlook-2019-2030-olive-oil-consumption-rise-non-producingeu-countries-2019-dec-10_en (accessed on 13 October 2021).

9. Gavahian, M.; Mousavi Khaneghah, A.; Lorenzo, J.M.; Munekata, P.E.S.; Garcia-Mantrana, I.; Collado, M.C.; Meléndez-Martínez, A.J.; Barba, F.J. Health benefits of olive oil and its components: Impacts on gut microbiota antioxidant activities, and prevention of noncommunicable diseases. Trends Food Sci. Technol. 2019, 88, 220-227. [CrossRef] 
10. Jimenez-Lopez, C.; Carpena, M.; Lourenço-Lopes, C.; Gallardo-Gomez, M.; Lorenzo, J.M.; Barba, F.J.; Prieto, M.A.; Simal-Gandara, J. Bioactive Compounds and Quality of Extra Virgin Olive Oil. Foods 2020, 9, 1014. [CrossRef]

11. Skinner, R.C.; Gigliotti, J.C.; Ku, K.M.; Tou, J.C. A comprehensive analysis of the composition, health benefits, and safety of apple pomace. Nutr. Rev. 2018, 76, 893-909. [CrossRef]

12. Bobinaitè, R.; Grootaert, C.; Van Camp, J.; Šarkinas, A.; Liaudanskas, M.; Žvikas, V.; Viškelis, P.; Rimantas Venskutonis, P. Chemical composition, antioxidant, antimicrobial and antiproliferative activities of the extracts isolated from the pomace of rowanberry (Sorbus aucuparia L.). Food Res. Int. 2020, 136, 109310. [CrossRef] [PubMed]

13. Abbasi-Parizad, P.; De Nisi, P.; Adani, F.; Sciarria, T.P.; Squillace, P.; Scarafoni, A.; Iametti, S.; Scaglia, B. Antioxidant and anti-inflammatory activities of the crude extracts of raw and fermented tomato pomace and their correlations with aglycatepolyphenols. Antioxidants 2020, 9, 179. [CrossRef]

14. Costabile, G.; Vitale, M.; Luongo, D.; Naviglio, D.; Vetrani, C.; Ciciola, P.; Tura, A.; Castello, F.; Mena, P.; Del Rio, D.; et al. Grape pomace polyphenols improve insulin response to a standard meal in healthy individuals: A pilot study. Clin. Nutr. 2019, 38, 2727-2734. [CrossRef] [PubMed]

15. Campos, D.A.; Gómez-García, R.; Vilas-Boas, A.A.; Madureira, A.R.; Pintado, M.M. Management of Fruit Industrial By-ProductsA case Study on Circular Economy Approach. Molecules 2020, 25, 320. [CrossRef] [PubMed]

16. European Union The EU Green Deal-A Roadmap to Sustainable Economies. Available online: https://bit.ly/39ydb5i (accessed on 1 December 2021).

17. Circular Economy Action Plan. Available online: https://ec.europa.eu/environment/strategy/circular-economy-action-plan_pt (accessed on 1 December 2021).

18. Munekata, P.E.S.; Nieto, G.; Pateiro, M.; Lorenzo, J.M. Phenolic compounds obtained from Olea europaea by-products and their use to improve the quality and shelf life of meat and meat products-A review. Antioxidants 2020, 9, 1061. [CrossRef] [PubMed]

19. Das, A.K.; Nanda, P.K.; Chowdhury, N.R.; Dandapat, P.; Gagaoua, M.; Chauhan, P.; Pateiro, M.; Lorenzo, J.M. Application of Pomegranate by-Products in Muscle Foods: Oxidative Indices, Colour Stability, Shelf Life and Health Benefits. Molecules 2021, 26, 467. [CrossRef] [PubMed]

20. Domínguez, R.; Gullón, P.; Pateiro, M.; Munekata, P.E.S.; Zhang, W.; Lorenzo, J.M. Tomato as potential source of natural additives for meat industry. A review. Antioxidants 2020, 9, 73. [CrossRef] [PubMed]

21. Mizael, W.C.F.; Costa, R.G.; Cruz, G.R.B.; de Carvalho, F.F.R.; Ribeiro, N.L.; Lima, A.; Domínguez, R.; Lorenzo, J.M. Effect of the use of tomato pomace on feeding and performance of lactating goats. Animals 2020, 10, 1574. [CrossRef] [PubMed]

22. Ianni, A.; Martino, G. Dietary grape pomace supplementation in dairy cows: Effect on nutritional quality of milk and its derived dairy products. Foods 2020, 9, 168. [CrossRef] [PubMed]

23. Quiles, A.; Campbell, G.M.; Struck, S.; Rohm, H.; Hernando, I. Fiber from fruit pomace: A review of applications in cereal-based products. Food Rev. Int. 2018, 34, 162-181. [CrossRef]

24. Gullón, P.; Gullón, B.; Romaní, A.; Rocchetti, G.; Lorenzo, J.M. Smart advanced solvents for bioactive compounds recovery from agri-food by-products: A review. Trends Food Sci. Technol. 2020, 101, 182-197. [CrossRef]

25. Cattaneo, C.; Lavelli, V.; Proserpio, C.; Laureati, M.; Pagliarini, E. Consumers' attitude towards food by-products: The influence of food technology neophobia, education and information. Int. J. Food Sci. Technol. 2019, 54, 679-687. [CrossRef]

26. Perito, M.A.; Di Fonzo, A.; Sansone, M.; Russo, C. Consumer acceptance of food obtained from olive by-products: A survey of Italian consumers. Br. Food J. 2020, 122, 212-226. [CrossRef]

27. Sabater, C.; Ruiz, L.; Delgado, S.; Ruas-Madiedo, P.; Margolles, A. Valorization of Vegetable Food Waste and By-Products Through Fermentation Processes. Front. Microbiol. 2020, 11, 2604. [CrossRef] [PubMed]

28. Koutinas, A.A.; Vlysidis, A.; Pleissner, D.; Kopsahelis, N.; Lopez Garcia, I.; Kookos, I.K.; Papanikolaou, S.; Kwan, T.H.; Lin, C.S.K. Valorization of industrial waste and by-product streams via fermentation for the production of chemicals and biopolymers. Chem. Soc. Rev. 2014, 43, 2587-2627. [CrossRef]

29. Muck, R.E.; Nadeau, E.M.G.; McAllister, T.A.; Contreras-Govea, F.E.; Santos, M.C.; Kung, L. Silage review: Recent advances and future uses of silage additives. J. Dairy Sci. 2018, 101, 3980-4000. [CrossRef] [PubMed]

30. Fang, J.; Xia, G.; Cao, Y. Effects of replacing commercial material with apple pomace on the fermentation quality of total mixed ration silage and its digestibility, nitrogen balance and rumen fermentation in wethers. Grassl. Sci. 2020, 66, 124-131. [CrossRef]

31. Xia, G.-J.; Fang, J.-C. Intake, digestibility and rumen fermentation pattern in wethers fed total mixed ration silage containing dry or fresh apple pomace. J. Anim. Feed Sci. 2021, 30, 26-32. [CrossRef]

32. Belém, C.d.S.; de Souza, A.M.; de Lima, P.R.; de Carvalho, F.A.L.; Queiroz, M.A.Á.; da Costa, M.M. Digestibility, fermentation and microbiological characteristics of Calotropis procera silage with different quantities of grape pomace. Cienc. Agrotecnologia 2016, 40, 698-705. [CrossRef]

33. Li, P.; Shen, Y.; You, M.; Zhang, Y.; Yan, J.; Li, D.; Bai, S. Effect of grape pomace on fermentation quality and aerobic stability of sweet sorghum silage. Anim. Sci. J. 2017, 88, 1523-1530. [CrossRef]

34. Köksal, Y.; Bölükbaş, B.; Selçuk, Z. An in vitro Evaluation of the Silages in White Mulberry Pomace/Meadow Grass mixtures containing different levels of White Mulberry Pomace. Kocatepe Vet. J. 2021, 14, 309-315. [CrossRef]

35. Fang, J.; Cao, Y.; Matsuzaki, M.; Suzuki, H.; Kimura, H. Effects of apple pomace-mixed silage on growth performance and meat quality in finishing pigs. Anim. Sci. J. 2016, 87, 1516-1521. [CrossRef] [PubMed] 
36. Davies, S.J.; Guroy, D.; Hassaan, M.S.; El-Ajnaf, S.M.; El-Haroun, E. Evaluation of co-fermented apple-pomace, molasses and formic acid generated sardine based fish silages as fishmeal substitutes in diets for juvenile European sea bass (Dicentrachus labrax) production. Aquaculture 2020, 521, 735087. [CrossRef]

37. Massaro Junior, F.L.; Bumbieris Junior, V.H.; Pereira, E.S.; Zanin, E.; Horst, E.H.; Calixto, O.P.P.; Peixoto, E.L.T.; Galbeiro, S.; Mizubuti, I.Y. Grape pomace silage on growth performance, carcass, and meat quality attributes of lambs. Sci. Agric. 2022, 79, 2022. [CrossRef]

38. Kafantaris, I.; Stagos, D.; Kotsampasi, B.; Hatzis, A.; Kypriotakis, A.; Gerasopoulos, K.; Makri, S.; Goutzourelas, N.; Mitsagga, C.; Giavasis, I.; et al. Grape pomace improves performance, antioxidant status, fecal microbiota and meat quality of piglets. Animal 2018, 12, 246-255. [CrossRef] [PubMed]

39. Gungor, E.; Altop, A.; Erener, G. Effect of raw and fermented grape pomace on the growth performance, antioxidant status, intestinal morphology, and selected bacterial species in broiler chicks. Animals 2021, 11, 364. [CrossRef] [PubMed]

40. Ibrahim, D.; Moustafa, A.; Shahin, S.E.; Sherief, W.R.I.A.; Abdallah, K.; Farag, M.F.M.; Nassan, M.A.; Ibrahim, S.M. Impact of Fermented or Enzymatically Fermented Dried Olive Pomace on Growth, Expression of Digestive Enzyme and Glucose Transporter Genes, Oxidative Stability of Frozen Meat, and Economic Efficiency of Broiler Chickens. Front. Vet. Sci. 2021, 8, 644325. [CrossRef] [PubMed]

41. Tuoxunjiang, H.; Yimamu, A.; Li, X.Q.; Maimaiti, R.; Wang, Y.L. Effect of ensiled tomato pomace on performance and antioxidant status in the peripartum dairy cow. J. Anim. Feed Sci. 2020, 29, 105-114. [CrossRef]

42. Gungor, E.; Altop, A.; Erener, G.; Coskun, I. Effect of raw and fermented pomegranate pomace on performance, antioxidant activity, intestinal microbiota and morphology in broiler chickens. Arch. Anim. Nutr. 2021, 75, 137-152. [CrossRef]

43. Siró, I.; Kápolna, E.; Kápolna, B.; Lugasi, A. Functional food. Product development, marketing and consumer acceptance-A review. Appetite 2008, 51, 456-467. [CrossRef] [PubMed]

44. Pathania, S.; Sharma, N.; Handa, S. Utilization of horticultural waste (Apple Pomace) for multiple carbohydrase production from Rhizopus delemar $\mathrm{F}_{2}$ under solid state fermentation. J. Genet. Eng. Biotechnol. 2018, 16, 181-189. [CrossRef]

45. Satapathy, S.; Soren, J.P.; Mondal, K.C.; Srivastava, S.; Pradhan, C.; Sahoo, S.L.; Thatoi, H.; Rout, J.R. Industrially relevant pectinase production from Aspergillus parvisclerotigenus KX928754 using apple pomace as the promising substrate. J. Taibah Univ. Sci. 2021, 15, 347-356. [CrossRef]

46. Kuvvet, C.; Uzuner, S.; Cekmecelioglu, D. Improvement of Pectinase Production by Co-culture of Bacillus spp. Using Apple Pomace as a Carbon Source. Waste Biomass Valorization 2019, 10, 1241-1249. [CrossRef]

47. Guleria, S.; Walia, A.; Chauhan, A.; Mahajan, R.; Shirkot, C.K. Mutagenesis of Alkalophilic Cellulosimicrobium sp. CKMX1 for Hyper-Production of Cellulase-Free Xylanase in Solid State Fermentation of Apple Pomace. Proc. Natl. Acad. Sci. India Sect. B Biol. Sci. 2015, 85, 241-252. [CrossRef]

48. Gassara, F.; Brar, S.K.; Tyagi, R.D.; Verma, M.; Surampalli, R.Y. Screening of agro-industrial wastes to produce ligninolytic enzymes by Phanerochaete chrysosporium. Biochem. Eng. J. 2010, 49, 388-394. [CrossRef]

49. Singh, R.S.; Chauhan, K.; Kaur, K.; Pandey, A. Statistical optimization of solid-state fermentation for the production of fungal inulinase from apple pomace. Bioresour. Technol. Rep. 2020, 9, 100364. [CrossRef]

50. Meini, M.R.; Ricardi, L.L.; Romanini, D. Novel Routes for Valorisation of Grape Pomace Through the Production of Bioactives by Aspergillus niger. Waste Biomass Valorization 2020, 11, 6047-6055. [CrossRef]

51. Kurt, A.S.; Cekmecelioglu, D. Bacterial cellulase production using grape pomace hydrolysate by shake-flask submerged fermentation. Biomass Convers. Biorefinery 2021, 1, 1-8. [CrossRef]

52. Papadaki, A.; Kachrimanidou, V.; Papanikolaou, S.; Philippoussis, A.; Diamantopoulou, P. Upgrading grape pomace through Pleurotus spp. cultivation for the production of enzymes and fruiting bodies. Microorganisms 2019, 7, 207. [CrossRef] [PubMed]

53. Teles, A.S.C.; Chávez, D.W.H.; Oliveira, R.A.; Bon, E.P.S.; Terzi, S.C.; Souza, E.F.; Gottschalk, L.M.F.; Tonon, R.V. Use of grape pomace for the production of hydrolytic enzymes by solid-state fermentation and recovery of its bioactive compounds. Food Res. Int. 2019, 120, 441-448. [CrossRef] [PubMed]

54. Papadaki, E.; Kontogiannopoulos, K.N.; Assimopoulou, A.N.; Mantzouridou, F.T. Feasibility of multi-hydrolytic enzymes production from optimized grape pomace residues and wheat bran mixture using Aspergillus niger in an integrated citric acid-enzymes production process. Bioresour. Technol. 2020, 309, 123317. [CrossRef] [PubMed]

55. Mahmoud, A.E.; Fathy, S.A.; Rashad, M.M.; Ezz, M.K.; Mohammed, A.T. Purification and characterization of a novel tannase produced by Kluyveromyces marxianus using olive pomace as solid support, and its promising role in gallic acid production. Int. J. Biol. Macromol. 2018, 107, 2342-2350. [CrossRef]

56. Leite, P.; Salgado, J.M.; Venâncio, A.; Domínguez, J.M.; Belo, I. Ultrasounds pretreatment of olive pomace to improve xylanase and cellulase production by solid-state fermentation. Bioresour. Technol. 2016, 214, 737-746. [CrossRef] [PubMed]

57. Oliveira, F.; Salgado, J.M.; Abrunhosa, L.; Pérez-Rodríguez, N.; Domínguez, J.M.; Venâncio, A.; Belo, I. Optimization of lipase production by solid-state fermentation of olive pomace: From flask to laboratory-scale packed-bed bioreactor. Bioprocess Biosyst. Eng. 2017, 40, 1123-1132. [CrossRef] [PubMed]

58. Paz, A.; Chalima, A.; Topakas, E. Biorefinery of exhausted olive pomace through the production of polygalacturonases and omega-3 fatty acids by Crypthecodinium cohnii. Algal Res. 2021, 59, 102470. [CrossRef] 
59. Belmessikh, A.; Boukhalfa, H.; Mechakra-Maza, A.; Gheribi-Aoulmi, Z.; Amrane, A. Statistical optimization of culture medium for neutral protease production by Aspergillus oryzae. Comparative study between solid and submerged fermentations on tomato pomace. J. Taiwan Inst. Chem. Eng. 2013, 44, 377-385. [CrossRef]

60. Boukhalfa-lezzar, H.; Copinet, E.; Duchiron, F.; Aicha, M. Utilization of tomato pomace as a substrate for neutral protease production by Aspergillus oryzae 2220 on solid-state fermentation. Artic. Int. J. Adv. Res. 2014, 2, 338-346.

61. Iandolo, D.; Piscitelli, A.; Sannia, G.; Faraco, V. Enzyme production by solid substrate fermentation of pleurotus ostreatus and trametes versicolor on tomato pomace. Appl. Biochem. Biotechnol. 2011, 163, 40-51. [CrossRef] [PubMed]

62. Torkashvand, N.; Mousivand, M.; Hashemi, M. Canola meal and tomato pomace as novel substrates for production of thermostable Bacillus subtilis T4b xylanase with unique properties. Biomass Convers. Biorefinery 2020, 1-13. [CrossRef]

63. Mahmoodi, M.; Najafpour, G.D.; Mohammadi, M. Production of pectinases for quality apple juice through fermentation of orange pomace. J. Food Sci. Technol. 2017, 54, 4123-4128. [CrossRef] [PubMed]

64. Mahmoodi, M.; Najafpour, G.D.; Mohammadi, M. Bioconversion of agroindustrial wastes to pectinases enzyme via solid state fermentation in trays and rotating drum bioreactors. Biocatal. Agric. Biotechnol. 2019, 21, 101280. [CrossRef]

65. Singh, R.S.; Chauhan, K.; Singh, J.; Pandey, A.; Larroche, C. Solid-state fermentation of carrot pomace for the production of inulinase by Penicillium oxalicum BGPUP-4. Food Technol. Biotechnol. 2018, 56, 31-39. [CrossRef] [PubMed]

66. Dey, T.B.; Banerjee, R. Application of decolourized and partially purified polygalacturonase and $\alpha$-amylase in apple juice clarification. Brazilian J. Microbiol. 2014, 45, 97-104. [CrossRef]

67. Cuprys, A.; Thomson, P.; Suresh, G.; Roussi, T.; Brar, S.K.; Drogui, P. Potential of agro-industrial produced laccase to remove ciprofloxacin. Environ. Sci. Pollut. Res. 2021, 1-10. [CrossRef] [PubMed]

68. Raveendran, S.; Parameswaran, B.; Ummalyma, S.B.; Abraham, A.; Mathew, A.K.; Madhavan, A.; Rebello, S.; Pandey, A. Applications of microbial enzymes in food industry. Food Technol. Biotechnol. 2018, 56, 16-30. [CrossRef]

69. Chapman, J.; Ismail, A.E.; Dinu, C.Z. Industrial applications of enzymes: Recent advances, techniques, and outlooks. Catalysts 2018, 8, 238. [CrossRef]

70. Gligor, O.; Mocan, A.; Moldovan, C.; Locatelli, M.; Crișan, G.; Ferreira, I.C.F.R. Enzyme-assisted extractions of polyphenols-A comprehensive review. Trends Food Sci. Technol. 2019, 88, 302-315. [CrossRef]

71. Dzah, C.S.; Duan, Y.; Zhang, H.; Serwah Boateng, N.A.; Ma, H. Latest developments in polyphenol recovery and purification from plant by-products: A review. Trends Food Sci. Technol. 2020, 99, 375-388. [CrossRef]

72. Zambrano, C.; Kotogán, A.; Bencsik, O.; Papp, T.; Vágvölgyi, C.; Mondal, K.C.; Krisch, J.; Takó, M. Mobilization of phenolic antioxidants from grape, apple and pitahaya residues via solid state fungal fermentation and carbohydrase treatment. LWT Food Sci. Technol. 2018, 89, 457-465. [CrossRef]

73. Dulf, F.V.; Vodnar, D.C.; Toşa, M.I.; Dulf, E.H. Simultaneous enrichment of grape pomace with $\gamma$-linolenic acid and carotenoids by solid-state fermentation with Zygomycetes fungi and antioxidant potential of the bioprocessed substrates. Food Chem. 2020, 310, 125927. [CrossRef] [PubMed]

74. Bucić-Kojić, A.; Fernandes, F.; Silva, T.; Planinić, M.; Tišma, M.; Šelo, G.; Šibalić, D.; Pereira, D.M.; Andrade, P.B. Enhancement of the anti-inflammatory properties of grape pomace treated by: Trametes versicolor. Food Funct. 2020, 11, 680-688. [CrossRef] [PubMed]

75. Lohani, U.C.; Muthukumarappan, K. Effect of sequential treatments of fermentation and ultrasonication followed by extrusion on bioactive content of apple pomace and textural, functional properties of its extrudates. Int. J. Food Sci. Technol. 2016, 51, 1811-1819. [CrossRef]

76. Madrera, R.R.; Pando Bedriñana, R.; Suárez Valles, B. Enhancement of the nutritional properties of apple pomace by fermentation with autochthonous yeasts. LWT Food Sci. Technol. 2017, 79, 27-33. [CrossRef]

77. Liu, L.; You, Y.; Deng, H.; Guo, Y.; Meng, Y. Promoting hydrolysis of apple pomace by pectinase and cellulase to produce microbial oils using engineered Yarrowia lipolytica. Biomass Bioenergy 2019, 126, 62-69. [CrossRef]

78. Dulf, F.V.; Vodnar, D.C.; Dulf, E.H.; Toşa, M.I. Total Phenolic Contents, Antioxidant Activities, and Lipid Fractions from Berry Pomaces Obtained by Solid-State Fermentation of Two Sambucus Species with Aspergillus niger. J. Agric. Food Chem. 2015, 63, 3489-3500. [CrossRef] [PubMed]

79. Fathy, S.A.; Mahmoud, A.E.; Rashad, M.M.; Ezz, M.K.; Mohammed, A.T. Improving the nutritive value of olive pomace by solid state fermentation of Kluyveromyces marxianus with simultaneous production of gallic acid. Int. J. Recycl. Org. Waste Agric. 2018, 7, 135-141. [CrossRef]

80. Paz, A.; Karnaouri, A.; Templis, C.C.; Papayannakos, N.; Topakas, E. Valorization of exhausted olive pomace for the production of omega-3 fatty acids by Crypthecodinium cohnii. Waste Manag. 2020, 118, 435-444. [CrossRef] [PubMed]

81. Dulf, F.V.; Vodnar, D.C.; Dulf, E.H.; Diaconeasa, Z.; Socaciu, C. Liberation and recovery of phenolic antioxidants and lipids in chokeberry (Aronia melanocarpa) pomace by solid-state bioprocessing using Aspergillus niger and Rhizopus oligosporus strains. LWT 2018, 87, 241-249. [CrossRef]

82. Dulf, F.V.; Vodnar, D.C.; Socaciu, C. Effects of solid-state fermentation with two filamentous fungi on the total phenolic contents, flavonoids, antioxidant activities and lipid fractions of plum fruit (Prunus domestica L.) by-products. Food Chem. 2016, 209, 27-36. [CrossRef] [PubMed]

83. Dulf, F.V.; Vodnar, D.C.; Dulf, E.H.; Pintea, A. Phenolic compounds, flavonoids, lipids and antioxidant potential of apricot (Prunus armeniaca L.) pomace fermented by two filamentous fungal strains in solid state system. Chem. Cent. J. 2017, 11, 1-10. [CrossRef] [PubMed] 
84. Zhu, Y.; Jiang, J.; Yue, Y.; Feng, Z.; Chen, J.; Ye, X. Influence of mixed probiotics on the the bioactive composition, antioxidant activity and appearance of fermented red bayberry pomace. LWT 2020, 133, 110076. [CrossRef]

85. Cheng, Y.; Wu, T.; Tang, S.; Liang, F.; Fang, Y.; Cao, W.; Pan, S.; Xu, X. Fermented blueberry pomace ameliorates intestinal barrier function through the NF-kB-MLCK signaling pathway in high-fat diet mice. Food Funct. 2020, 11, 3167-3179. [CrossRef] [PubMed]

86. Cheng, Y.; Tang, S.; Huang, Y.; Liang, F.; Fang, Y.; Pan, S.; Wu, T.; Xu, X. Lactobacillus casei-fermented blueberry pomace augments sIgA production in high-fat diet mice by improving intestinal microbiota. Food Funct. 2020, 11, 6552-6564. [CrossRef] [PubMed]

87. Yan, Y.; Zhang, F.; Chai, Z.; Liu, M.; Battino, M.; Meng, X. Mixed fermentation of blueberry pomace with L. rhamnosus GG and L. plantarum-1: Enhance the active ingredient, antioxidant activity and health-promoting benefits. Food Chem. Toxicol. 2019, 131, 110541. [CrossRef] [PubMed]

88. Espinosa-Pardo, F.A.; Nakajima, V.M.; Macedo, G.A.; Macedo, J.A.; Martínez, J. Extraction of phenolic compounds from dry and fermented orange pomace using supercritical $\mathrm{CO}_{2}$ and cosolvents. Food Bioprod. Process. 2017, 101, 1-10. [CrossRef]

89. Dittoe, D.K.; Ricke, S.C.; Kiess, A.S. Organic acids and potential for modifying the avian gastrointestinal tract and reducing pathogens and disease. Front. Vet. Sci. 2018, 5, 216. [CrossRef] [PubMed]

90. Deng, L.Z.; Mujumdar, A.S.; Pan, Z.; Vidyarthi, S.K.; Xu, J.; Zielinska, M.; Xiao, H.W. Emerging chemical and physical disinfection technologies of fruits and vegetables: A comprehensive review. Crit. Rev. Food Sci. Nutr. 2020, 60, 2481-2508. [CrossRef] [PubMed]

91. Halla, N.; Fernandes, I.P.; Heleno, S.A.; Costa, P.; Boucherit-Otmani, Z.; Boucherit, K.; Rodrigues, A.E.; Ferreira, I.C.F.R.; Barreiro, M.F. Cosmetics preservation: A review on present strategies. Molecules 2018, 23, 1571. [CrossRef]

92. Golmohammadzadeh, R.; Faraji, F.; Rashchi, F. Recovery of lithium and cobalt from spent lithium ion batteries (LIBs) using organic acids as leaching reagents: A review. Resour. Conserv. Recycl. 2018, 136, 418-435. [CrossRef]

93. Vashisht, A.; Thakur, K.; Kauldhar, B.S.; Kumar, V.; Yadav, S.K. Waste valorization: Identification of an ethanol tolerant bacterium Acetobacter pasteurianus SKYAA25 for acetic acid production from apple pomace. Sci. Total Environ. 2019, 690, 956-964. [CrossRef] [PubMed]

94. Parmar, I.; Rupasinghe, H.P.V. Bio-conversion of apple pomace into ethanol and acetic acid: Enzymatic hydrolysis and fermentation. Bioresour. Technol. 2013, 130, 613-620. [CrossRef] [PubMed]

95. Piwowarek, K.; Lipińska, E.; Hać-Szymańczuk, E.; Rudziak, A.; Kieliszek, M. Optimization of propionic acid production in apple pomace extract with Propionibacterium freudenreichii. Prep. Biochem. Biotechnol. 2019, 49, 974-986. [CrossRef] [PubMed]

96. Piwowarek, K.; Lipińska, E.; Hać-Szymańczuk, E.; Kot, A.M.; Kieliszek, M.; Bonin, S. Use of Propionibacterium freudenreichii T82 strain for effective biosynthesis of propionic acid and trehalose in a medium with apple pomace extract and potato wastewater. Molecules 2021, 26, 3965. [CrossRef]

97. Ali, S.R.; Anwar, Z.; Irshad, M.; Mukhtar, S.; Warraich, N.T. Bio-synthesis of citric acid from single and co-culture-based fermentation technology using agro-wastes. J. Radiat. Res. Appl. Sci. 2016, 9, 57-62. [CrossRef]

98. Das, R.K.; Brar, S.K.; Verma, M. A fermentative approach towards optimizing directed biosynthesis of fumaric acid by Rhizopus oryzae 1526 utilizing apple industry waste biomass. Fungal Biol. 2015, 119, 1279-1290. [CrossRef]

99. Das, R.K.; Lonappan, L.; Brar, S.K.; Verma, M. Bio-conversion of apple pomace into fumaric acid in a rotating drum type solid-state bench scale fermenter and study of the different underlying mechanisms. RSC Adv. 2015, 5, 104472-104479. [CrossRef]

100. Madrera, R.R.; Bedriñana, R.P.; Valles, B.S. Production and characterization of aroma compounds from apple pomace by solid-state fermentation with selected yeasts. LWT Food Sci. Technol. 2015, 64, 1342-1353. [CrossRef]

101. Ricci, A.; Cirlini, M.; Guido, A.; Liberatore, C.M.; Ganino, T.; Lazzi, C.; Chiancone, B. From byproduct to resource: Fermented apple pomace as beer flavoring. Foods 2019, 8, 309. [CrossRef]

102. Hadj Saadoun, J.; Ricci, A.; Cirlini, M.; Bancalari, E.; Bernini, V.; Galaverna, G.; Neviani, E.; Lazzi, C. Production and recovery of volatile compounds from fermented fruit by-products with Lacticaseibacillus rhamnosus. Food Bioprod. Process. 2021, 128, 215-226. [CrossRef]

103. Antonić, B.; Jančíková, S.; Dordević, D.; Tremlová, B. Grape pomace valorization: A systematic review and meta-analysis. Foods 2020, 9, 1627. [CrossRef]

104. Vidal, A.; Ouhibi, S.; Ghali, R.; Hedhili, A.; De Saeger, S.; De Boevre, M. The mycotoxin patulin: An updated short review on occurrence, toxicity and analytical challenges. Food Chem. Toxicol. 2019, 129, 249-256. [CrossRef] [PubMed]

105. Yeni, F.; Yavaş, S.; Alpas, H.; Soyer, Y. Most Common Foodborne Pathogens and Mycotoxins on Fresh Produce: A Review of Recent Outbreaks. Crit. Rev. Food Sci. Nutr. 2016, 56, 1532-1544. [CrossRef] 